\title{
A 1-D mechanistic model for the evolution of earthflow-prone hillslopes
}

\author{
Adam M. Booth ${ }^{1}$ and Josh J. Roering ${ }^{1}$ \\ Received 9 March 2011; revised 23 August 2011; accepted 24 August 2011; published 12 November 2011. \\ [1] In mountainous terrain, deep-seated landslides transport large volumes of material \\ on hillslopes, exerting a dominant control on erosion rates and landscape form. Here, \\ we develop a mathematical landscape evolution model to explore interactions between \\ deep-seated earthflows, soil creep, and gully processes at the drainage basin scale \\ over geomorphically relevant $\left(>10^{3}\right.$ year) timescales. In the model, sediment flux or \\ incision laws for these three geomorphic processes combine to determine the morphology \\ of actively uplifting and eroding steady state topographic profiles. We apply the model \\ to three sites, one in the Gabilan Mesa, California, with no earthflow activity, and two \\ along the Eel River, California, with different lithologies and varying levels of historic \\ earthflow activity. Representative topographic profiles from these sites are consistent \\ with model predictions in which the magnitude of a dimensionless earthflow number, \\ based on a non-Newtonian flow rheology, reflects the magnitude of recent earthflow \\ activity on the different hillslopes. The model accurately predicts the behavior of earthflow \\ collection and transport zones observed in the field and estimates long-term average \\ sediment fluxes that are due to earthflows, in agreement with historical rates at our field \\ sites. Finally, our model predicts that steady state hillslope relief in earthflow-prone \\ terrain increases nonlinearly with the tectonic uplift rate, suggesting that the mean \\ hillslope angle may record uplift rate in earthflow-prone landscapes even at high uplift \\ rates, where threshold slope processes normally limit further topographic development.
}

Citation: Booth, A. M., and J. J. Roering (2011), A 1-D mechanistic model for the evolution of earthflow-prone hillslopes, J. Geophys. Res., 116, F04021, doi:10.1029/2011JF002024.

\section{Introduction}

[2] In mountainous terrain, landslides often transport large volumes of material on hillslopes, exerting an important control on long-term erosion rate and therefore a landscape's topographic form. Especially where uplift rates are high, landslides may be the dominant mechanism of hillslope erosion [Schmidt and Montgomery, 1995; Burbank et al., 1996; Korup et al., 2007]. However, the high spatial and temporal variability of landslide motion and occurrence makes it challenging to infer long-term erosion rates due to landsliding using either short-term measurements or observations of landscape-scale topographic characteristics. Specifically, mapping active landslides and interpreting the morphology of inactive landslides can be a subjective and time-consuming process [Guzzetti et al., 2000; Wills and McCrink, 2002], relationships between landslide frequency, area, and volume used to determine erosion rates often have high uncertainties [Hovius et al., 1997; Stark and Hovius, 2001; Malamud et al., 2004; Brunetti et al., 2009; Guzzetti et al., 2009], and few

\footnotetext{
${ }^{1}$ Department of Geological Sciences, University of Oregon, Eugene, Oregon, USA.

Copyright 2011 by the American Geophysical Union. 0148-0227/11/2011JF002024
}

quantitative models exist for predicting landslide response to changes in climatic or tectonic forcing [Densmore et al., 1998]. Although several studies have utilized quantitative models of shallow landsliding to predict landscape response to changes in climate or uplift rate [Tucker and Bras, 1998; van der Beek et al., 1999; Istanbulluoglu and Bras, 2005], comparable studies of deep-seated landslide processes are lacking. In this study we characterize deep-seated landslides as those that incorporate some fresh or weathered bedrock and are more than several meters deep, in contrast to shallow landslides, which incorporate only soil and colluvium and are less than a few meters deep. Because of the above challenges, most studies addressing the role of deep-seated landslides in landscape evolution have focused on coarse topographic characteristics such as the distribution of hillslope angles at the mountain range scale [Schmidt and Montgomery, 1995; Burbank et al., 1996; Montgomery and Brandon, 2002; Gabet et al., 2004; Korup, 2008], despite the existence of many detailed, site-specific studies of individual landslides [e.g. Cruden and Krahn, 1973; Iverson and Major, 1987; Kilburn and Petley, 2003; Coe et al., 2003]. Few studies have addressed time and spatial scales intermediate to these two extremes in order to determine the role of deep-seated landslides in shaping hillslopes within a drainage basin [Miller, 1995; Roering et al., 2005]. 
[3] Mathematical landscape evolution modeling is one method for exploring the interactions between deep-seated landslides and other surface processes at this intermediate scale. In a landscape evolution model (LEM), equations for sediment fluxes or incision rates due to different geomorphic processes govern the temporal evolution of the land surface elevation [Ahnert, 1976; Willgoose et al., 1991a, 1991b; Tucker and Bras, 1998]. Numerous studies have utilized geomorphic transport laws [Dietrich et al., 2003], which describe these fluxes in the context of landscape evolution, to infer geomorphic process rates based on landscape morphology or to simulate landscape response to changing process intensities [e.g. Kirkby, 1971; Tucker and Slingerland, 1994; Kooi and Beaumont, 1996; van der Beek et al., 1999; Roering et al., 2007; Perron et al., 2009]. However, many of these models are limited to processes that can be easily approximated as varying slowly in both time and space. Few attempts have been made to generalize and include a geomorphic transport law for deep-seated landslide processes. Ahnert [1977, 1987] included a plastic flow term in numerical models to simulate slow mass movements if a threshold was exceeded, and Kirkby [1987] also developed a one-dimensional model for hillslope evolution including landsliding. Notably and more recently, Densmore et al. [1998] created a numerical landscape evolution model that produced realistic mountainous terrain and landslide frequency-magnitude statistics, while Hergarten and Neugebauer [1998, 1999] created a numerical model that exhibited self-organized criticality in landslide behavior. However, these studies' rule sets for deep-seated landslide initiation, movement, and deposition, although reasonable, are challenging to calibrate and not directly applicable to all types of deep-seated landslides, particularly the large, deepseated earthflow failures that dominate many mountainous areas. For example, landslides in Densmore et al.'s [1998] model are rapid, with motion and deposition occurring in a single time step, while in Hergarten and Neugebauer's [1998, 1999] model, landslides controlled solely by the magnitude of a depth-slope product are the lone geomorphic agent acting at the surface. Here, we propose a rheologybased description of landslide initiation, movement, and deposition, and focus on the interactions among deep-seated landsliding, near-surface soil creep, and fluvial gully processes. We develop a landscape evolution model motivated by our observations of deep-seated earthflow behavior at a study site along the Eel River, northern California, but keep the model general to ensure it can be adapted to deep-seated landslides in diverse geologic settings.

[4] Slope failures at the Eel River study site are slow, composite earth slide-earth flows [Cruden and Varnes, 1996], which we refer to simply as earthflows. At this site, earthflows transport weathered material, including blocks of weathered bedrock, downslope at rates of $\sim 0.1$ to $5 \mathrm{~m} \mathrm{yr}^{-1}$ with shear strain, concentrated in bands ranging from narrow slip surfaces to meter-thick zones of distributed shear, responsible for most of the deformation. Movement is seasonal, with the onset of fast movement occurring once winter rainfall events elevate pore pressures sufficiently, as observed at a nearby earthflow [Iverson and Major, 1987]. In the study area, movements of active earthflows may temporarily become negligible during dry periods, while exceptionally wet periods may drive movement rates up to several meters per year [Mackey and Roering, 2011]. This style of slope failure commonly occurs in clay-rich, highly weathered lithologies such as the Franciscan mélange of the California coast ranges [Kelsey, 1978; Keefer and Johnson, 1983; Iverson, 1986a; Mackey et al., 2009; Mackey and Roering, 2011], which underlies the Eel River study site. Similar slope failures occur throughout the world in mechanically weak lithologies and have been extensively documented in the north island of New Zealand [Crozier, 1968; Gage and Black, 1979; McSaveney and Griffiths, 1987; Trotter, 1993], Japan [Matsukura and Mizuno, 1986], the Oregon Cascades [Swanson and Swanston, 1977; Pyles et al., 1987] and southern France [Malet et al., 2002; Maquaire et al., 2003].

[5] In addition to earthflows, gullying and soil creep act to determine the morphology of hillsopes along the Eel River. Feedbacks between gullying and earthflow deformation may occur both on the lower sections of earthflows with deeply incised central or marginal gullies, and on higher sections containing extensive but often disconnected networks of smaller gullies. For example, changes in the position and depth of the gully network affect the flow of groundwater within an earthflow, as discussed for earthflow microtopography by Iverson and Major [1987], which affects pore pressures within an earthflow. Roering et al. [2009] noted a correspondence between the fastest moving portion of an earthflow and a region with a high density of deep, connected gullies, and suggested that this network facilitated sediment removal from this part of the earthflow. Additionally, Mackey and Roering [2011] proposed that sediment transport in discontinuous gullies can redistribute mass near earthflow headscarps, which changes the state of stress in the underlying earthflow and alters movement. Surficial soil creep, driven by biologic or mechanical processes that dilate the soil, primarily smooths small-scale topographic roughness such as gully banks or hummocky topography associated with earthflow deformation.

[6] These three processes, earthflows, soil creep, and gullying, act across an earthflow-prone landscape, driving changes in the land surface elevation over time. Our mechanistic mathematical model aims to capture the interactions among these processes over timescales that allow the full development of defining landscape characteristics such as hillslope length, profile form, and local relief. This necessitates averaging the behavior of each modeled process over many periods of activity and quiescence while retaining its essential components, as is common in many landscape evolution models [Dietrich et al., 2003]. Because individual earthflows can remain active for hundreds to thousands of years [Kelsey, 1978; Bovis and Jones, 1992; Mackey et al., 2009], we adopt a minimum timescale of $10^{3}$ years as geomorphically significant for the purposes of this study.

[7] We begin formulating a landscape evolution model for earthflow-prone terrain by combining expressions for sediment flux due to earthflows and soil creep with an expression for incision due to fluvial gully processes in a mass balance framework. In the model, earthflows behave as a non-Newtonian viscous fluid deforming under gravitational stress, soil creep is a slope-dependent diffusive process, and stream power determines the rate of fluvial incision via gullying. We then illustrate how changes in nondimensional parameters describing each process in the model control the form of a hillslope profile. To apply the model to our Eel 


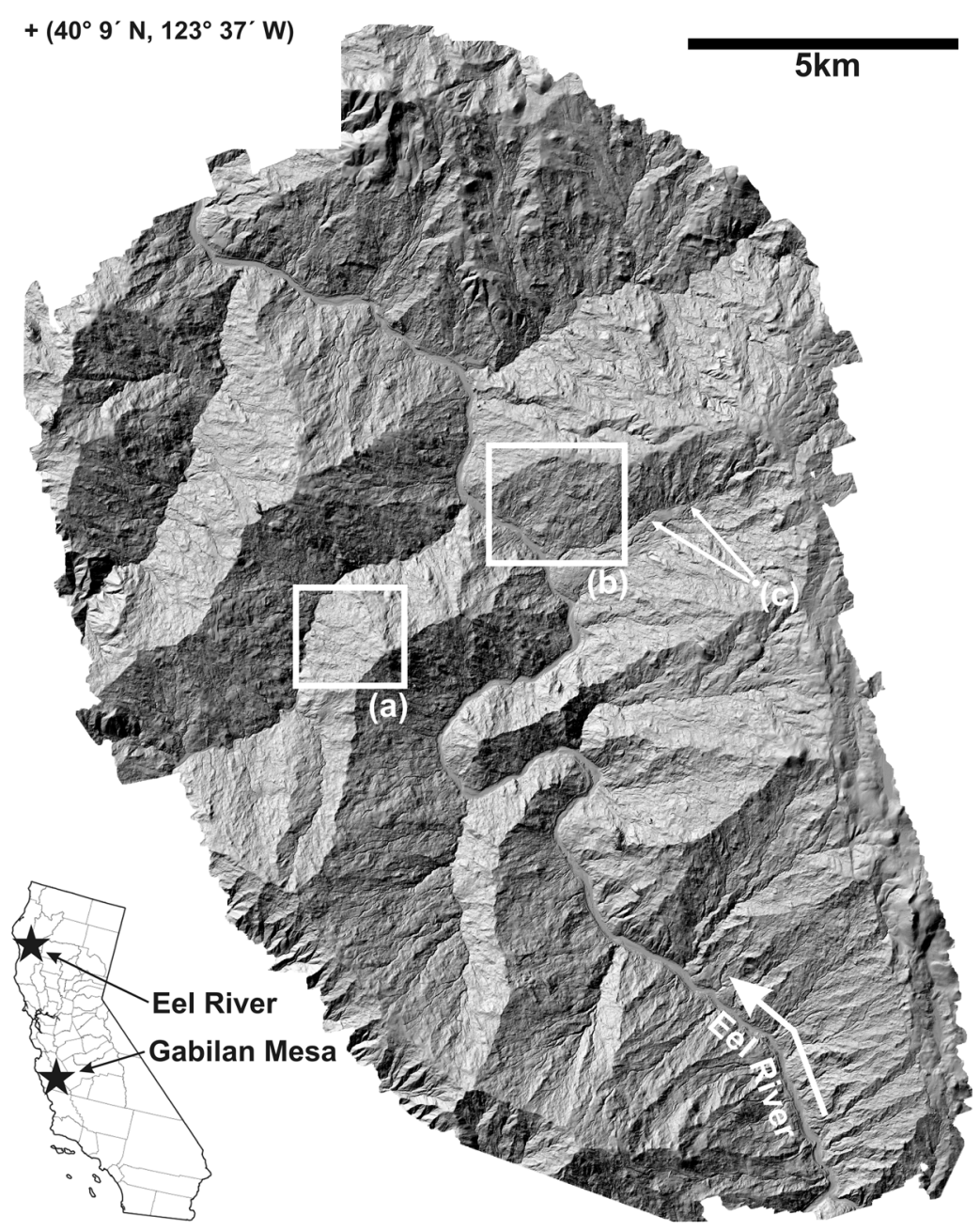

Figure 1. Lidar-derived hillshade map of the Eel River study area. Hillslopes used to test our LEM, as described in section 4, (a) in a sandstone lithology and (b) in an argillaceous mélange lithology. (c) Approximate indication of the perspective view shown in Figures $2 \mathrm{a}$ and $2 \mathrm{~b}$.

River study site, as well as to a control site in the Gabilan Mesa, California, with no earthflow activity, we use Monte Carlo simulations to determine unique combinations of model parameters that best match representative profiles from the study areas. These model-generated profiles allow us to infer spatial patterns of erosion along a hillslope profile due to each modeled geomorphic process. Parameter values from the Monte Carlo simulations also yield estimates of the long-term average sediment flux due to each process, which we compare to observed process rates in the study areas. Last, using our most earthflow-prone study site as a reference state, we predict how changes in uplift rate and modeled earthflow parameters affect hillslope relief.

\section{Study Areas: Eel River and Gabilan Mesa, California}

[8] We develop our model for deep-seated earthflowprone terrain based on observations of a study site along the Eel River, northern California (Figure 1). Bedrock there consists mainly of the central belt of the Franciscan Complex, part of a metamorphosed and tectonically sheared Jurassic-Cretaceous accretionary prism [Jayko et al., 1989;
McLaughlin et al., 2000]. A sheared mélange unit consisting mainly of meta-argillite underlies most of the terrain to the east of the Eel River in the study area and is especially prone to earthflows. Isolated blocks of chert, greenstone, and serpentinite occur within this unit, and these blocks commonly form local topographic highs less susceptible to earthflows than the surrounding hillslopes. To the west of the Eel River in the study area, the bedrock is mainly metasandstone and meta-argillite of the Broken Formation, which contains few highly sheared rocks. McLaughlin et al. [2000] note differences in the topographic expressions of these two units, with poorly incised and irregular topography in the mélange and well-incised, regular drainages in the Broken Formation. Figure 2 illustrates the typical earthflow-prone topography of the mélange unit, where active and relict earthflow features such as headscarps, lateral levees, hummocks, and discontinuous gully networks cover nearly the entire hillslope. We select a representative hillslope from the Broken Formation (Figure 1a) to test our model in moderately earthflow-prone terrain and from the mélange unit (Figure 1b) to test our model in pervasively earthflow-prone terrain. We carried out topographic analyses using a $1 \mathrm{~m}$ resolution lidar-derived digital elevation 
(a)

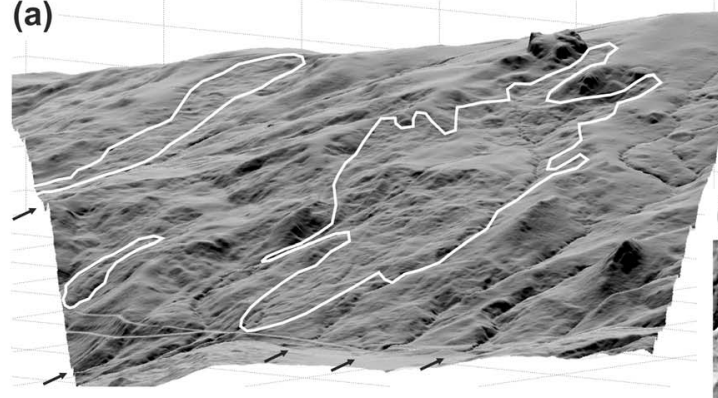

(b)
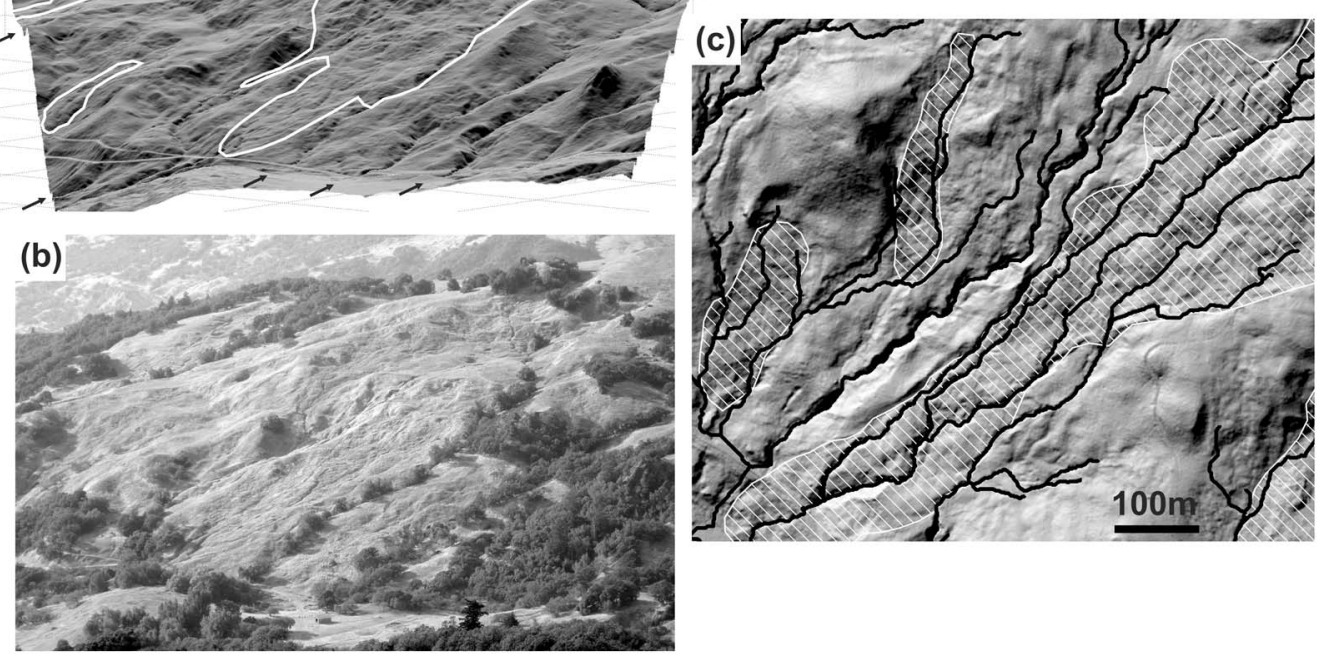

Figure 2. (a, b) Perspective view from Figure 1c, illustrating the typical geomorphology of earthflowprone hillslopes in our Eel River study area. Figure 2a is a bare earth $1 \mathrm{~m}$ DEM draped with a hillshade map to approximate the same lighting and view angle as in Figure 2b, which is a photograph (barn in the central foreground for scale). In Figure 2a, the white outlines highlight three historically active earthflows [Mackey and Roering, 2011], and the black arrows indicate several of the more prominent and numerous small gullies incised on both active and relict earthflows. In addition to the active earthflows, relict headscarps, lateral levees, and hummocky topography cover most of the remaining hillslope, clearly indicating past generations of earthflow activity. Only a small portion of the hillslope, such as the smooth, rounded ridge at the upper right, lacks topographic signs of past earthflow failure. Figure $2 \mathrm{c}$ shows a more detailed view (center of Figure 5c) of a gully network incised into both active (white cross-hatched polygons) and relict earthflow features. Black lines show the steepest descent paths through this gully network.

model (DEM) produced by the National Center for Airborne Laser Mapping (NCALM) in 2006.

[9] The Eel River study area and surrounding mountains are currently experiencing rock uplift due to the northward migration of the Mendocino Triple Junction [Furlong and Schwartz, 2004]. Neither rock uplift nor erosion rate at the study site is known, but several studies have determined these rates in the vicinity. Rock uplift rates on the nearby coast range up to $4 \mathrm{~mm} \mathrm{yr}^{-1}$ as inferred from Holocene and late Pleistocene marine terraces [Merritts and Vincent, 1989]. Fuller et al. [2009] used ${ }^{10} \mathrm{Be}$ concentrations in strath terrace sediments and optically stimulated luminescence to estimate Pleistocene to Holocene erosion rates ranging from 0.07 to $0.35 \mathrm{~mm} \mathrm{yr}^{-1}$ in the nearby South Fork Eel River catchment. Finally, the modern, catchment-averaged erosion rate for the entire Eel River drainage basin, determined from 1950 to 2000 using suspended sediment data, is $\sim 0.9 \mathrm{~mm} \mathrm{yr}^{-1}$ [Wheatcroft and Sommerfield, 2005]. Our site is probably not experiencing a bedrock uplift rate as high as reported by Merritts and Vincent [1989] because their highest rates are confined to the tectonically distinct King Range [Dumitru, 1991], but it may be uplifting more rapidly than the South Fork [Fuller et al., 2009] because of its present location just south and east of the Mendocino Triple Junction. Furlong and Govers [1999] predicted a peak in uplift to the south of the northward migrating Mendocino Triple Junction using a geodynamic model, while Lock et al. [2006] estimated an uplift rate for this peak of 0.5 to $1 \mathrm{~mm} \mathrm{yr}^{-1}$ currently located near the northern end of the Eel River study site. We therefore adopt an uplift rate of the order of $1 \mathrm{~mm} \mathrm{yr}^{-1}$ in this study, which also agrees with the modern erosion rate averaged over the entire catchment. This choice of uplift rate does not affect our model formulation or application to the study sites, but it does influence the magnitude of the sediment fluxes calculated in section 4.3.

[10] To highlight differences between earthflow-prone terrain and other landscapes not influenced by landslides, we contrast the topographic characteristics of our Eel River study area with a site in the Gabilan Mesa, California (Figures 1 and 5a). This site shows no signs of earthflow or other landslide activity and typifies gentle, convex ridgevalley topography common for first-order basins in soilmantled terrain [Montgomery and Dietrich, 1992] resulting from a competition between near-surface soil creep and channelized fluvial processes [Perron et al., 2008]. The Gabilan Mesa consists mainly of massively bedded, continental gravel and sand of the Paso Robles Formation, which conformably overlie Pliocene shallow marine sediment [Christensen, 1965; Galehouse, 1967]. Christensen [1965] 
determined that the base of the Paso Robles formation in the vicinity of the study site has uplifted $\sim 1000 \mathrm{ft}$ over the last 2 or 3 million years, which gives an average rock uplift rate of 0.1 to $0.15 \mathrm{~mm} \mathrm{yr}^{-1}$ since the Pleistocene. Using exposure and burial ages from cosmogenic radionuclides, Perron et al. [2005] determined a surface age of 86 to $464 \mathrm{kyr}$ for unincised remnants of the original Gabilan Mesa surface $\sim 80 \mathrm{~m}$ above the modern valley bottoms, which gives an incision rate of 0.14 to $0.74 \mathrm{~mm} \mathrm{yr}^{-1}$ over this time period [Roering et al., 2007]. The strikingly uniform valley spacing [Perron et al., 2008, 2009] and uniform ridgetop curvature [Roering et al., 2007] suggest that the Gabilan Mesa is likely in a topographic steady state such that the erosion rate approximately balances the rock uplift rate. We adopt an uplift rate of $0.3 \mathrm{~mm} \mathrm{yr}^{-1}$, near the center of the range reported above, and emphasize that this choice affects only the magnitude of the calculated sediment fluxes in section 4.3. We utilize a $1 \mathrm{~m}$ DEM of the Gabilan Mesa (Figure 5a), also produced by NCALM, for our analyses.

[11] To systematically capture the morphologic characteristics of the Eel River landscape, we generate a slopearea plot using all lidar grid points in the study area except those in the main stem of the Eel River (Figure 3). At each grid point, the magnitude of the topographic gradient, calculated using its four nearest neighbors, determines the slope and a steepest descent algorithm determines the drainage area. To determine the drainage area in streams whose headwaters are outside the study area, we supplement the $1 \mathrm{~m}$ DEM with a 1/3 arc second resolution DEM available from the Unites States Geologic Survey National Map Seamless Server (http://seamless.usgs.gov/). Figure 2 also shows a slope-area plot for the Gabilan Mesa, digitized from Dietrich and Perron [2006], who utilized a $2 \mathrm{~m}$ DEM, to highlight differences between the two sites.

[12] In the Eel River study area, topographic gradient tends to slowly decrease from $\sim 0.35$ to $\sim 0.20$ as the drainage area increases up to $\sim 10^{6} \mathrm{~m}^{2}$. These locations occupy the $>1 \mathrm{~km}$ long, low-angle hillslopes that make up over $99 \%$ of the terrain in the study area (Figure 3, right axis), nearly all of which show signs of previous or current earthflow and gully activities (Figure 2). On this typical Eel River hillslope (Figures 2a and 2b), a patchwork of several historically active earthflows [Mackey and Roering, 2011] and hummocky topography, lateral levees, and headscarps from previous earthflow activity cover most of the slope. Several prominent gullies and networks of smaller, discontinuous gullies are incised over much of the hillslope. Figure 2c shows a more detailed view of a gully network incised into active and relict earthflow features. At areas greater than $\sim 10^{6} \mathrm{~m}^{2}$, the topographic gradient decreases slightly more rapidly up to a drainage area of $\sim 10^{7} \mathrm{~m}^{2}$, where it abruptly decreases to $<0.1$ (Figure 3 ). This transitional drainage area is typical of the main tributaries to the Eel River (Figure 1) and coincident with a transition to a sediment transport regime dominated by fluvial processes in the major rivers bounding the long, low-angle hillslopes.

[13] The slope-area characteristics of the Eel River study site contrast sharply with those of the Gabilan Mesa. There, at small drainage areas of less than $10^{2} \mathrm{~m}^{2}$, the topographic gradient increases rapidly with drainage area, tracking the transition from broad, gentle ridgetops to steeper hillslopes over a horizontal distance of tens of meters. Mean topo- graphic gradients at the Eel River site, however, are much greater over this same range of drainage areas and exhibit only a subtle increase followed by a subtle decrease in magnitude, because of the lack of well-developed ridge-valley topography at this short length scale. At drainage areas of $\sim 10^{2} \mathrm{~m}^{2}$, both sites have similar average topographic gradients, but the topographic gradient decreases much more rapidly with increasing drainage area at the Gabilan Mesa site, to $<0.1$ at a drainage area of $\sim 10^{5} \mathrm{~m}^{2}$. Topographic gradients at the Eel River site do not attain a similar value for another 2 orders of magnitude in drainage area, or until $\sim 10^{7} \mathrm{~m}^{2}$. This difference reflects the two sites' vastly different hillslope length scales: in the Gabilan Mesa, locations with drainage areas much larger than $\sim 10^{2} \mathrm{~m}^{2}$ are found only in the well-developed fluvial network, while locations with similar drainage areas in the Eel River study area are found within gullies that incise active or relict earthflows on this site's $>1 \mathrm{~km}$ long hillslopes. Although differences in denudation rate and relief between the two sites could cause a significant difference in drainage density and therefore hillslope length scale [Kirkby, 1987; Howard, 1997; Oguchi, 1997; Tucker and Bras, 1998], we suggest that the greater than order of magnitude difference in hillslope length scales likely results from earthflows inhibiting the formation of small-scale ridge-valley topography and effectively lengthening hillslopes.

\section{Model Formulation}

[14] The morphology of hillslopes in the Eel River study site (Figure 2) suggests that earthflows, gullies, and soil creep interact across the landscape to create the topographic signature revealed by the slope-area analysis described above. Our model therefore aims to capture the dynamics of interactions between these processes and to estimate their contributions to landscape form. To capture the first-order effects of earthflows on topographic form over geomorphically significant timescales, we combine a mechanistic mathematical expression for sediment flux due to earthflows with similar mechanistic expressions for soil creep flux and gully incision in a simple one-dimensional (1-D) landscape evolution model based on steady state mass flux. The model simulates the evolution of the land surface elevation as a competition between these three processes, with each process affecting the entire modeled hillslope through time and driving the hillslope profile toward a different end-member steady state solution. By allowing each of these processes to continuously shape the modeled hillslope, we emphasize process interactions, especially between earthflows and gullies, and determine the role each plays in shaping topography over $>10^{3}$ year timescales. Our model is based on the Eel River study site, but we intentionally keep the model general so that it may be adaptable to other landscapes where landslide processes can be described as a flux of material with a characteristic velocity and depth. Below, we first develop each component of the model independently then we combine the components into a mass balance and derive a nondimensional governing equation for generating steady state solutions.

\subsection{Soil Creep}

[15] In soil-mantled landscapes, dilational disturbances of the near surface caused by biological and mechanical 


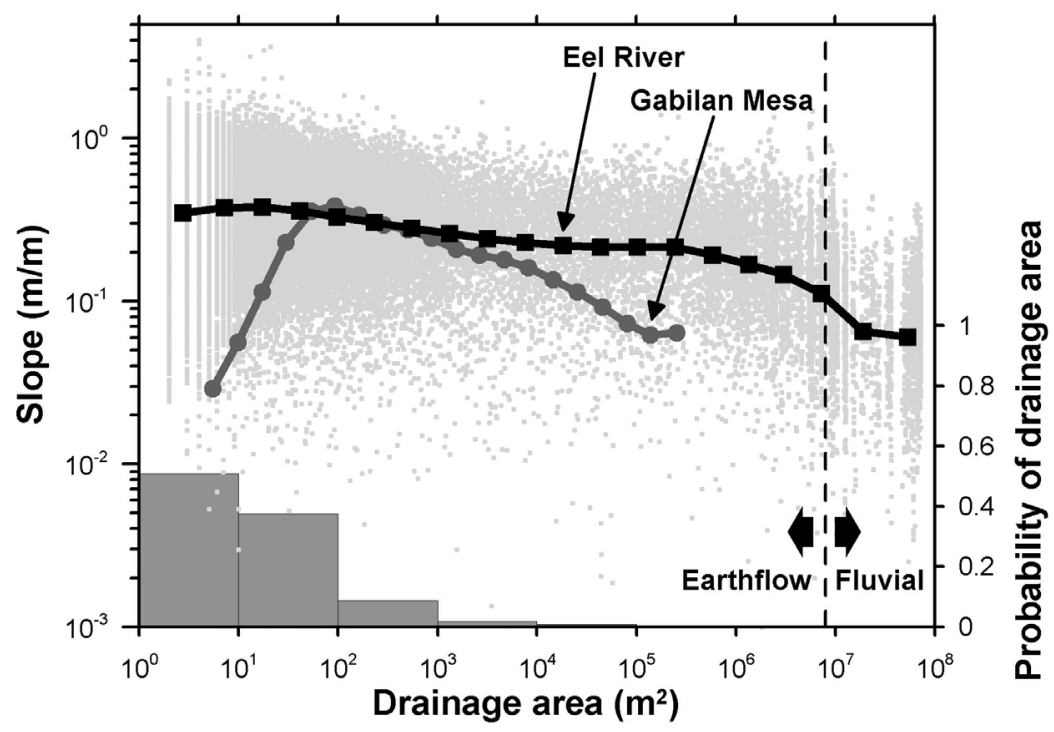

Figure 3. (left) Slope-area plots for the Eel River and Gabilan Mesa study sites, and (right) histogram of drainage area for the Eel River study site. On the left axis, the small grey points show the local topographic gradient and upslope drainage area at each grid point in the Eel River study area, the large black squares connected with a thick black line show the logarithmically binned mean, and the vertical dashed line approximately indicates the transition to a sediment transport regime dominated by fluvial processes. For comparison, the large grey circles connected with a thick line show a slope-area plot from the Gabilan Mesa, California, a site with no landslide activity, digitized from Dietrich and Perron [2006]. Standard errors are smaller than the symbols for both study sites. All $\sim 1.5 \times 10^{8}$ grid points with their complete drainage area contained within the DEM (Figure 1) were used to calculate the binned mean and standard error for the Eel River site, but for clarity, only a random subsample of points is shown. On the right axis, the grey bars indicate the proportion of all grid points in the DEM with drainage areas falling within each order of magnitude bin.

processes, including vegetation growth, animal burrowing, and frost heave, result in a net downslope flux of sediment [Selby, 1993]. Gilbert [1877, 1909] and Davis [1892] first proposed that this creep-driven flux should increase with topographic gradient, resulting in convex hillslopes. Culling [1960] later formalized this observation into a mathematical model by assuming that sediment flux is directly proportional to the topographic gradient, and studies have since provided field evidence for a model of this form using cosmogenic radionuclides [McKean et al., 1993; Small et al., 1999]. Following this body of work we describe the sediment flux per unit contour width that is due to soil creep $q_{s}$ (with units of $\mathrm{L}^{2} \mathrm{~T}^{-1}$ ), in one dimension as

$$
q_{s}=-D \frac{\partial z}{\partial x}
$$

where $D$ is a diffusive proportionality constant $\left(\mathrm{L}^{2} \mathrm{~T}^{-1}\right), z$ is the land surface elevation (L) and $x$ is horizontal distance from the drainage divide (L). For a hillslope in dynamic equilibrium with a uniform erosion rate, equation (1) predicts that the magnitude of the topographic gradient increases linearly with distance from the drainage divide, resulting in a convex parabolic hillslope form (Figure 4, light grey line) [Culling, 1960]. However, as hillslopes steepen, this linear approximation gives way to a nonlinear dependence of the sediment flux on the topographic gradient [Howard, 1994; Roering et al., 1999], limiting the applicability of equation (1) to gently sloping, soil-mantled ter- rain. Topographic gradients are $0.39 \pm 0.22$ and $0.36 \pm 0.18$ (mean \pm 1 standard deviation) in the Eel River and Gabilan Mesa study areas, respectively, for which there is little difference between the linear and nonlinear models [Roering et al., 1999].

\subsection{Gully Incision}

[16] Flow of water in a channel exerts a shear stress on its bed, resulting in the detachment and subsequent transport of sediment. The erosion rate of the bed therefore increases with shear stress, as expressed in the common stream power model for detachment-limited channels [Howard and Kerby, 1983]:

$$
\dot{\varepsilon}_{g}=K A^{m} S^{n},
$$

In equation (2), $\dot{\varepsilon}_{g}$ is the incision rate $\left(\mathrm{L} \mathrm{T}^{-1}\right), K$ is the coefficient of erosion $\left(\mathrm{L}^{1-2 m} \mathrm{~T}^{-1}\right), A$ is drainage area $\left(\mathrm{L}^{2}\right)$, $S$ is channel slope, and $m$ and $n$ are dimensionless constants. We favor this detachment-limited model over a transport-limited model because we frequently observe bedrock exposed in gullies in the study area, indicating that flows can remove most temporarily stored sediment from the channel and that in the long term a gully's ability to be incised depends on the ability of flowing water to dislodge large boulders or detach fresh bedrock [Whipple and Tucker, 2002]. We do not observe debris flow deposits in these gullies and therefore do not include a formulation of incision or deposition due to debris flows in our model. The drainage 

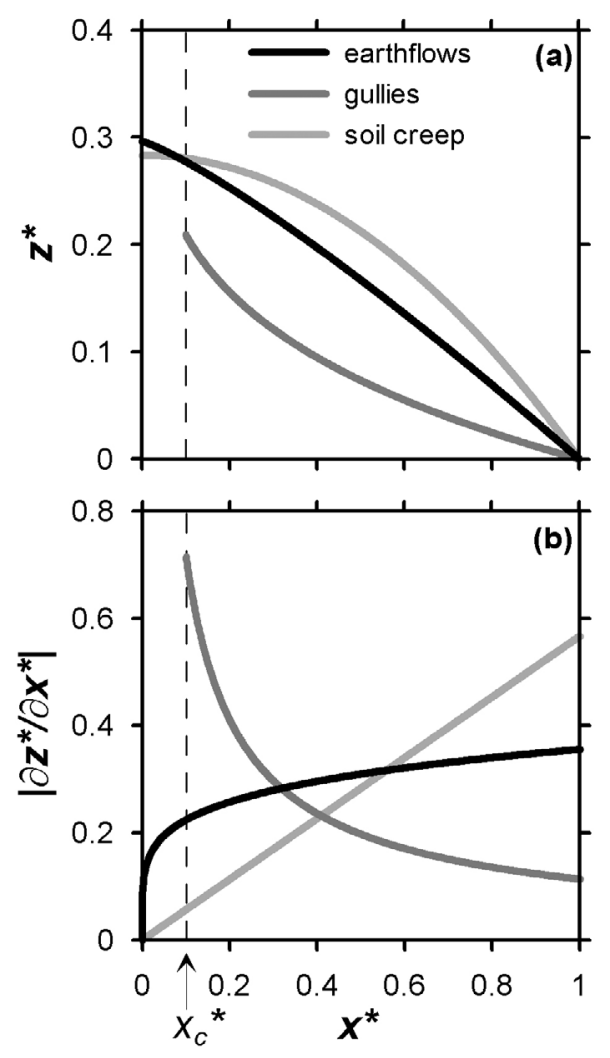

Figure 4. (a) Normalized elevation and (b) topographic gradient versus distance from the drainage divide for representative steady state model-generated profiles with only soil creep (lightest grey), gully incision (medium grey), or earthflow deformation (black) active. All distances are normalized to the hillslope length, and the exponents used to generate these curves are $h m=0.8, n=1$, and $p=5$.

area, $A$, in equation (2) serves as a proxy for an effective water discharge, and the exponent $m$ therefore reflects the hydraulic geometry of the channel, the drainage basin hydrology, and the dependence of incision on shear stress. The exponent $n$ reflects only the dependence of incision on shear stress and therefore may contain information about the physical mechanisms of erosion responsible for lowering the bed [Whipple and Tucker, 1999]. To apply the stream power model to our 1-D model, we assume that the drainage area increases with distance from the drainage divide according to Hack's law [Hack, 1957], such that

$$
A=k_{a} x^{h}
$$

where $k_{a}\left(\mathrm{~L}^{2-h}\right)$ and $h$ are constants. Substituting equation (3) into equation (2) gives

$$
\dot{\varepsilon}_{g}=K k_{a}^{m} x^{h m}\left|\frac{\partial z}{\partial x}\right|^{n}
$$

where the parallel bracket indicates absolute value, which describes the incision rate at each point along the modeled profile. For a channel experiencing steady state erosion, equation (4) predicts a concave profile with the channel gradient decreasing smoothly in the downstream direction
(Figure 4, medium grey line). To simulate a threshold drainage area for channel incision, we apply equation (4) only where $x>x_{c}$, where $x_{c}$ is a critical distance from the ridgetop, determined by matching the model to observed profiles in section 4.1.

\subsection{Earthflow Flux and Weathering}

[17] Earthflows transport sediment downslope through a combination of internal deformation and frictional slip on a shear surface [Brunsden, 1984; Keefer and Johnson, 1983; Zhang et al., 1991; Swanston et al., 1995]. In the former case, strain can be distributed throughout the earthflow mass, but is usually concentrated in a centimeter- to meterthick zone near the base with plug-like flow near the surface [Keefer and Johnson, 1983; Iverson, 1986a; Pyles et al., 1987] such that deformation of material within this shear zone controls the downslope flux. In the latter case, shear strain is localized on a single failure surface, so frictional properties of the failure surface control the flux of the material above it. In particular, feedbacks between pore pressure and dilation across a failure surface may strongly control shear localization and earthflow motion over seasonal [Iverson and Major, 1987; Hilley et al., 2004; Iverson, 2005] and even daily [Schulz et al., 2009] timescales. However, it remains unclear how the displacement on and the location of a given failure surface evolve over longer than seasonal timescales. Borehole measurements and other observations of earthflow shear zones often reveal multiple failure surfaces at different depths [Brunsden, 1984; Trotter, 1993], as well as distributed deformation across centimeterto meter-thick zones at a given time [Keefer and Johnson, 1983; Iverson, 1986a; Pyles et al., 1987]. Furthermore, models of earthflow movement based on Coulomb failure, including dilation and pore pressure interactions, focus on small displacements over short periods of time on a singleslip surface [Iverson, 2005].

[18] To extend these field observations and detailed models to longer timescales, we note that the deepest shear zones or failure surfaces are typically just above the interface between unweathered bedrock and weathered earthflow material [Swanson and Swanston, 1977; Trotter, 1993], indicating that in the long-term the position of this weathering front sets the depth of earthflow activity [Crozier, 1968; Gage and Black, 1979]. These observations suggest that in order for earthflows to persist in a landscape, the location of shear, either distributed or localized, tends to migrate downward in approximate concordance with the weathering front over geomorphically significant timescales. For the shear zone to migrate downward faster than the weathering front, it would have to deform stronger, unweathered bedrock, which is not consistent with our field observations. Conversely, if the weathering front migrated downward more rapidly than the shear zone, the shear stress at the weathering front would increase, making deformation of this weathered material at depth more likely. Over time, these two opposing effects (higher material strength below the weathered zone and low driving stresses near the surface) would tend to focus the shear zone where driving stress is high and the material is weak, at the interface between fresh and weathered bedrock.

[19] Here, we seek the first-order effects of earthflow motion on landscape evolution over these long timescales 
$\left(>10^{3}\right.$ years) and so choose to approximate sediment flux by earthflow processes as a continuous non-Newtonian flow of all weathered material above the bedrock interface. In doing so, we assume that there is a characteristic earthflow thickness, set by the average depth of weathering, as described above, and that a steadily deforming, non-Newtonian flow effectively averages across periods of faster and slower earthflow motion. This treatment does not explicitly include the behavior of individual, short-lived failure surfaces or episodes of earthflow activity and quiescence, but instead parameterizes the long-term behavior of earthflows through the constants of the flow law.

[20] The general relationship between stress and strain rates in a non-Newtonian fluid, assuming that variations in viscosity with strain rate are much greater than variations in normal stress differences [Barnes et al., 1989], is

$$
\dot{e}_{i j}=a\left|\sigma_{I I}\right|^{p-1} \sigma_{i j},
$$

where $\dot{e}_{i j}$ is a component of the strain rate tensor $\left(\mathrm{T}^{-1}\right), a$ is a constant $\left(\mathrm{L}^{p} \mathrm{M}^{-p} \mathrm{~T}^{2 p-1}\right), \sigma_{\mathrm{II}}$ is the second invariant of the stress tensor $\left(\mathrm{M} \mathrm{L}^{-1} \mathrm{~T}^{-2}\right), p$ is a dimensionless flow law exponent, and $\sigma_{i j}$ is the corresponding component of the stress tensor $\left(\mathrm{M} \mathrm{L} \mathrm{L}^{-1} \mathrm{~T}^{-2}\right)$. For an earthflow modeled as a 1-D, uniform, gravity-driven non-Newtonian flow, shear in the downslope direction is the only significant component of the stress tensor, so the shear strain rate is

$$
\frac{\partial u^{\prime}}{\partial z^{\prime}}=a\left(\rho_{e} g\left(H^{\prime}-z^{\prime}\right) \sin \theta\right)^{p},
$$

where the prime notation refers to a coordinate system aligned with the slope such that $u^{\prime}$ is the slope-parallel velocity $\left(\mathrm{L} \mathrm{T}^{-1}\right), z^{\prime}$ is the slope-normal coordinate (L) with $z^{\prime}=0$ at the base of the earthflow, $\rho_{e}$ is the density of weathered earthflow material $\left(\mathrm{M} \mathrm{L}^{-3}\right), g$ is acceleration that is due to gravity $\left(\mathrm{L} \mathrm{T}^{-2}\right), H^{\prime}$ is slope-normal earthflow thickness (L), and $\theta$ is the slope angle. For $p \geq 1$, this rheology can represent a range of behaviors from a Newtonian viscous fluid $(p=1)$ to a completely plastic material $(p \rightarrow \infty)$. The value of $p$ therefore controls the thickness of the shear zone relative to the depth of the flow, with moderate values of $\sim 5-10$ giving a narrow shear zone in general agreement with the observations described above. Iverson [1986a, 1986b, 1986c] used a similar rheologybased approach to investigate the response of an earthflow to perturbations to its stress field, while Vulliet and Hutter [1988a, 1988b, 1988c] and Vulliet [2000] have accurately predicted the deformation of slow-moving landslides using a similar rheology in a finite element model. We extend this rheology-based modeling approach to investigate landscape evolution by generalizing equation (6) to a form that can be easily combined with equations (1) and (4) in a mass balance framework.

[21] Integrating equation (6) twice with respect to $z^{\prime}$ and making use of the small-angle approximation [Turcotte and Schubert, 2002, p. 311] gives an expression for the depthaveraged flux per unit contour width due to earthflow movement, $q_{e}\left(\mathrm{~L}^{2} \mathrm{~T}^{-1}\right)$, as

$$
q_{e}=\frac{a\left(\rho_{e} g|\partial z / \partial x|\right)^{p} H^{p+2}}{p+2},
$$

where $H$ is the vertical earthflow thickness (L). We use the magnitude of the surface slope so that for any $p \geq 1$, equation (7) always gives a real value for the flux in the positive direction when $x \geq 0$. Assuming uniform, steady state uplift at a rate $U\left(\mathrm{~L} \mathrm{~T}^{-1}\right)$ and erosion of material with density $\rho_{e}$ along the entire length of a profile, equation (7) predicts that the topographic gradient varies as

$$
\left|\frac{\partial z}{\partial x}\right|=\frac{|x|^{1 / p}}{\rho_{e} g H^{1+2 / p}}\left(\frac{U(p+2)}{a}\right)^{1 / p},
$$

which gives a topographic profile that transitions from convex to near planar with distance from the drainage divide when $p>1$ (Figure 4, black line). By applying this expression for earthflow flux to geomorphically significant timescales in our 1-D model, we assume that there is a characteristic earthflow thickness, $H$, and material parameters, $a$ and $p$, that adequately describe the long-term behavior of earthflows in the study area. Equation (7) has the form of a geomorphic transport law [Dietrich et al., 2003] where the flux of material depends on some material parameters and the local topography and so easily incorporates into a landscape evolution model.

\subsection{Governing Equation and Nondimensionalization}

[22] Conservation of mass in one dimension requires that along a hillslope profile affected by the three geomorphic processes described above, the land surface elevation changes with time as

$$
\frac{\partial z}{\partial t}=\frac{\rho_{r}}{\rho_{e}} U-\frac{\partial}{\partial x}\left(q_{s}+q_{e}\right)-\dot{\varepsilon}_{g},
$$

where $t$ is time (T), $\rho_{r}$ is the bulk density of intact bedrock $\left(\mathrm{M} \mathrm{L}^{-3}\right)$, and $U$ is the uplift rate relative to a base level $\left(\mathrm{L} \mathrm{T}^{-1}\right)$. In further developing our landscape evolution model we note that soil creep and earthflow processes are active over the entire length of hillslopes in the Eel River study area, while gullies do not form until after accumulating a small threshold drainage area. We therefore allow $q_{s}$ and $q_{e}$ to be nonzero everywhere along the modeled hillslope profile, but allow $\varepsilon_{g}$ to be nonzero only beyond a critical distance, $x_{c}(\mathrm{~L})$, from the ridgetop to simulate a threshold for channel incision. Changes in the land surface elevation at a point on the profile result from competition between all three modeled processes for $x \geq x_{c}$, and a competition between just soil creep and earthflows for $0 \leq x<x_{c}$. Smith and Bretherton [1972], Howard [1994], Tucker and Bras [1998], and Perron et al. [2008], for example, previously used similar process competition-based models where both hillslope and channel processes act at every point in the landscape. We do not include a threshold for earthflow deformation because nearly all points in the Eel River study area show signs of past earthflow activity, and earthflows therefore appear to be continuously active enough over the long term, relative to soil creep and gully processes, to maintain their expression in the topography. Substituting equations (1), (4), and (7) into (9) and simplifying gives

$$
\frac{\partial z}{\partial t}=\frac{\rho_{r}}{\rho_{e}} U+D \frac{\partial^{2} z}{\partial x^{2}}-\frac{a\left(\rho_{e} g\right)^{p} H^{p+2}}{p+2} \frac{\partial}{\partial x}\left(\left|\frac{\partial z}{\partial x}\right|^{p}\right)-K k_{a}^{m} x^{h m}\left|\frac{\partial z}{\partial x}\right|^{n},
$$


which describes the rate of change of the land surface elevation at each point along a one-dimensional hillslope profile for $x \geq x_{c}$. For $0 \leq x<x_{c}$, we simply set the last term on the right-hand side of equation (10) equal to 0 . Each term on the right-hand side represents a contribution to the change in the land surface elevation due to a specific modeled geomorphic process. The first term describes vertical motion of bedrock and its change in density due to weathering, which supplies mobile, weathered material that can be transported by geomorphic processes. The second term describes surficial soil creep as a diffusive process, where elevation is the quantity being diffused, which primarily smooths the topography in areas of high profile curvature. The third term represents earthflow deformation, which transports weathered material of thickness $H$ downslope according to the nonNewtonian flow rheology described in section 3.3. The last term describes detachment-limited incision due to flow of water in gullies.

[23] To better understand how the terms in equation (10) control the form of a modeled hillslope profile, we recast it in terms of dimensionless variables. This facilitates comparison of the relative importance of each of the terms and simplifies analysis of the modeled hillslope response to changes in forcing parameters. We first use hillslope profile length, $\ell$, as a characteristic length scale, and the ratio of hillslope length to uplift rate, $\ell / U$, or the time it takes to uplift one hillslope length in the vertical direction, as a characteristic timescale to substitute the following into equation (10):

$$
z^{*}=z / \ell, x^{*}=x / \ell, H^{*}=H / \ell, \text { and } t^{*}=t U / \ell .
$$

Four nondimensional groups result:

$$
\begin{gathered}
\rho^{*}=\frac{\rho_{r}}{\rho_{e}}, \\
D^{*}=\frac{D}{U \ell}, \\
V^{*}=\frac{a\left(\rho_{w} g\right)^{p} H^{p+2}}{U \ell(p+2)}, \\
K^{*}=\frac{K k_{a}^{m} \ell^{h m}}{U},
\end{gathered}
$$

which characterize the relative magnitude of each modeled geomorphic process. The first is the density ratio of fresh bedrock to weathered earthflow material. The second is the ratio of the characteristic uplift timescale, $\ell / U$, to the characteristic timescale for diffusion of a feature of size $\ell$. The third is the ratio of the uplift timescale to a characteristic timescale for a non-Newtonian flow, which is the time required for a flow with thickness $H$ and a surface slope of 1 to transport $\ell^{2}$ of sediment past a reference point. The last is the ratio of the uplift timescale to the timescale for a kinematic wave, such as a knickpoint, to propagate a distance $\ell$ in the upstream direction. The magnitudes of $D^{*}, V^{*}$, or $K^{*}$ quantify the intensity of the three main processes transporting sediment in the study area, soil creep, earthflows, and gullies, respectively, with higher values indicating more vigorous geomorphic activity with respect to uplift. The relative magnitudes of $D^{*}, V^{*}$, and $K^{*}$ reflect the relative intensities among each of the modeled geomorphic processes.
[24] The nondimensional version of the governing equation for our LEM is then

$$
\frac{\partial z^{*}}{\partial t^{*}}=\rho^{*}+D^{*} \frac{\partial^{2} z^{*}}{\partial x^{* 2}}-V^{*} \frac{\partial^{*}}{\partial x^{*}}\left(\left|\frac{\partial z^{*}}{\partial x^{*}}\right|^{p}\right)-K^{*} x^{* h m}\left|\frac{\partial z^{*}}{\partial x^{*}}\right|^{n}
$$

where each nondimensional parameter given in equations (12a)-(12d) controls the relative contribution of each term on the right-hand side to changes in the land surface elevation. In taking this approach, we capture the general, firstorder behavior of the modeled processes in a way that is consistent with basic dimensional analysis and can be easily applied to the study area. Specifically, we assume that a change in any of the dimensionless parameters $D^{*}, V^{*}$, and $K^{*}$ adequately encompasses a change in any of the dimensional parameters in a way that captures the dynamic behavior of the modeled system. For example, a change in any of the parameters on the right-hand side of equation (12c), such as earthflow thickness or density, affects $V^{*}$, but the magnitude of $V^{*}$ alone should capture the essential characteristics of the modeled topographic profile.

\subsection{Steady State Solutions}

[25] For steady state denudation, each geomorphic process included in our model (equation (13)) drives the modeled hillslope profile toward a distinct topographic form. As a result, different topographic forms reflect the relative importance of the various geomorphic processes within the context of the model. Figure 4 gives examples of modeled steady state topographic profiles with soil creep, earthflows, or gully incision acting independently. If only soil creep transports sediment $\left(V^{*}, K^{*}=0\right)$, the magnitude of the topographic gradient increases linearly with distance from the drainage divide, and elevation decreases as $x^{* 2}$. If earthflows are the only mechanism for transporting sediment $\left(D^{*}, K^{*}=0\right)$, the topographic gradient first increases rapidly with distance from the divide, then increases gradually, leading to an elevation profile that transitions from convex to quasi-planar. If gully incision is the only geomorphic process acting along the profile $\left(D^{*}, V^{*}=0\right)$, both the topographic gradient and the elevation decrease from a maximum value at the channel head (where $x^{*}=x_{c}{ }^{*}$ ) rapidly at first, then more gradually, generating a broad concave morphology.

[26] If all three of these geomorphic processes act in competition along the modeled hillslope, profiles reflect a blend of the three end-members described above, which the values of $D^{*}, V^{*}$, and $K^{*}$ describe quantitatively. Equation (13) can thus be a tool for predicting the steady state topographic form, given estimates of these controlling parameters. Conversely, a given steady state profile resulting from a unique combination of model parameters, as we will show in section 4.1 , can provide a means for estimating values of these parameters at a particular site. Below, we exploit this quantitative relationship between topographic form and geomorphic process to infer values for $D^{*}, V^{*}$, and $K^{*}$ and estimate sediment fluxes due to different geomorphic processes at the study sites.

\section{Results}

[27] To demonstrate the utility of our model for making quantitative predictions about the behavior of earthflow-prone 

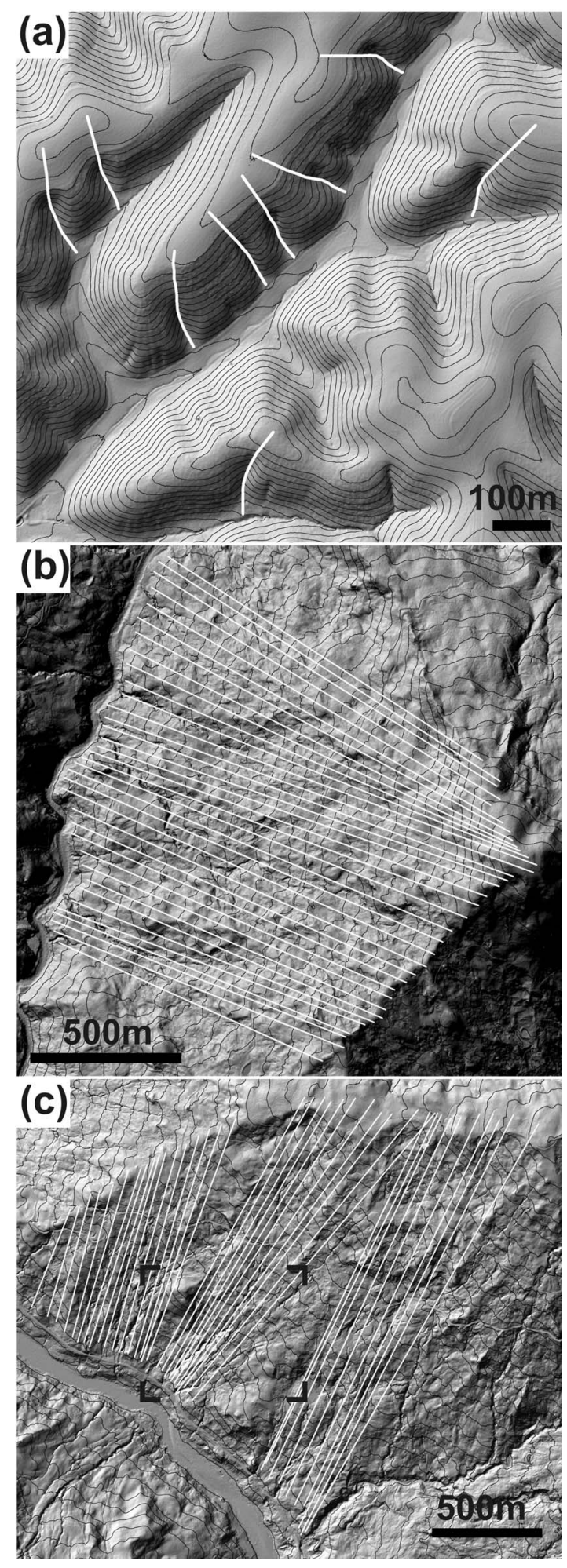

Figure 5. Lidar-derived hillshade maps of sites used to compare steady state model solutions to representative topographic profiles from (a) the Gabilan Mesa site, (b) the Eel River sandstone site, and (c) the Eel River mélange site. The white lines indicate locations of individual profiles averaged to determine the representative profile at each site. The contour interval is $5 \mathrm{~m}$ in Figure $5 \mathrm{a}$, and $20 \mathrm{~m}$ in Figures $5 \mathrm{~b}$ and $5 \mathrm{c}$. A detailed view of the area in rectangular brackets in Figure $5 \mathrm{c}$ is shown in Figure 2c. terrain, we apply it to our Gabilan Mesa and Eel River study sites. The Gabilan Mesa site (Figure 5a), which shows no signs of earthflow activity, serves as a control to demonstrate that, given a topographic profile, the model does not falsely predict any sediment flux due to earthflow activity where there is none. The first Eel River site (Figure 5b) is underlain by the Broken Formation metasandstones and shows some minor historic earthflow activity, while the second (Figure 5c) is underlain by the weaker mélange lithology and shows major historic earthflow activity [Mackey and Roering, 2011]. We first demonstrate that the model can generate steady state topographic profiles in good agreement with representative profiles observed in each of these distinctive sites using reasonable values for the free parameters. Next, we highlight along-profile patterns of steady state erosion due to each of the modeled geomorphic processes and discuss implications for the study areas. We then calculate long-term average sediment fluxes due to each of the modeled geomorphic processes along the representative profiles, which are in agreement with modern rates observed in the study areas. Last, we illustrate how changes in modeled earthflow behavior affect predicted hillslope relief under varying rates of tectonic forcing.

\subsection{Matching Observed Profiles}

[28] As a first test of our LEM, we utilize Monte Carlo simulations to determine combinations of the parameters $D^{*}, V^{*}, K^{*}, x_{c}{ }^{*}$, and $\mathrm{hm} / n$ that generate steady state solutions to equation (13) that best match representative topographic profiles at the three sites with varying levels of historic earthflow activity. We determine representative profiles at these sites by extracting 9-37 profiles from the $1 \mathrm{~m}$ resolution lidar DEMs, normalizing the profiles by their length and then averaging the elevations at 100 evenly spaced, interpolated points along each profile. Figure 5 shows the locations of the profiles, and Figure 6 shows the resulting representative profiles from each site. At the Gabilan Mesa site our profiles capture the first-order hillslope-valley transition so that both soil creep acting on the convex ridges and fluvial incision acting in the channels shape the representative profile. At the Eel River sites, we select straight profiles that extend nearly the full length of the long, quasiplanar hillslopes in order to include the competing effects of earthflows, gullies, and soil creep. This method of selecting profiles captures the general topographic form of the hillslope, which records the integrated effects of geomorphic processes acting over time, rather than that of a specific earthflow or gully, and aligns with the goals of our steady state, process competition model.

[29] In our Monte Carlo simulations, we numerically solve equation (13) for the steady state topographic gradient as a function of normalized distance from the drainage divide for random combinations of the parameters $D^{*}, V^{*}$, $K^{*}, x_{c}{ }^{*}$, and $h m / n$ over the ranges given in Table 1 . To solve equation (13) at steady state, we set $\partial z^{*} / \partial t^{*}=0$ and solve for $\partial S^{*} / \partial x^{*}$, where $S^{*}=\left|\partial z^{*} / \partial x^{*}\right|$; then we integrate this differential equation from the drainage divide, where $S^{*}=0$, to the foot of the hillslope at $x^{*}=1$ using a stiff ordinary differential equation solver in Matlab (The Mathworks, Inc.) [Shampine and Reichelt, 1997]. This allows all uplifted material to be transported across the hillslope boundary at $x^{*}=1$ at steady state, simulating the efficient removal of sediment by the actively incising rivers that bound our 


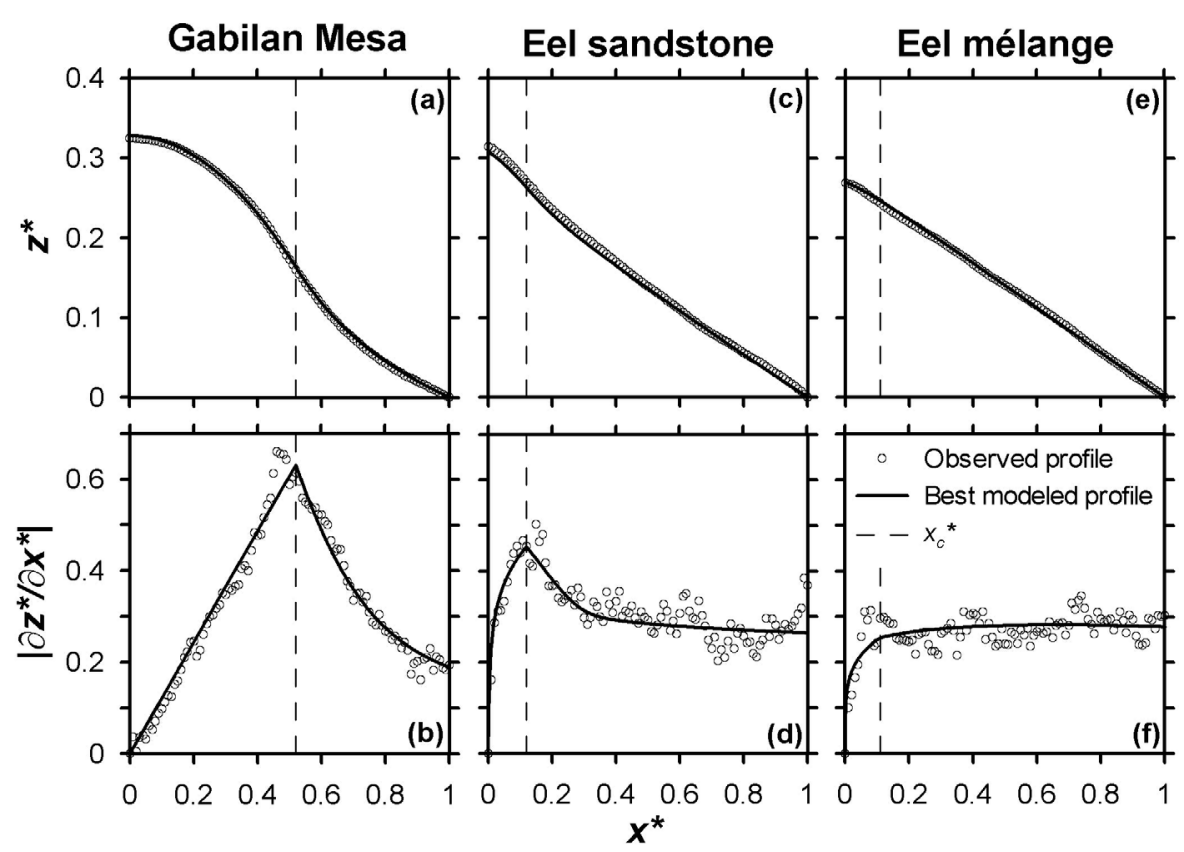

Figure 6. Representative and best fit hillslope profiles from (a, b) the Gabilan Mesa, (c, d) the Eel River sandstone, and $(e, f)$ the Eel River mélange sites. Minimum misfits given in Table 1 are determined from the normalized topographic gradients at each site (Figures $5 \mathrm{~b}, 5 \mathrm{~d}$, and $5 \mathrm{f}$ ).

representative hillslopes. For each combination, we calculate the misfit (RMS error) between the modeled and normalized observed profiles and determine the combination of model parameters that minimizes the misfit. On the basis of initial simulations over a wider range of parameters, we selected the parameter ranges reported in Table 1 so that they include the combination that minimizes this misfit and illustrate the dependence of misfit on each parameter in the vicinity of the best fit value. Initial simulations also indicated that the minimum misfit is not sensitive to $\rho^{*}$ or $p$, as long as $p>3$, at any of the three sites, so we set these parameters to reasonable values of $\rho^{*}=1.6$ and $p=5$. This estimate for $\rho^{*}$ is based on typical rock to soil density ratios [Selby, 1993], while the estimate for $p$ gives a reasonable plug-flow rheology and is in agreement with the range of values reported by Vulliet and Hutter [1988a, 1988b] and Vulliet [2000]. No modeled profiles match the observed profiles well when $p<3$. The misfit at the Gabilan Mesa site is not very sensitive to $\mathrm{hm} / \mathrm{n}$, so we set this ratio to $0.63(h=1.8, m=0.35$ and $n=1$ ), as by Perron et al. [2009] and making use of Hack's Law (equation (3)) [Hack, 1957], at that site only. The remaining parameters $D^{*}, V^{*}, K^{*}$, and $x_{c}^{*}$ are chosen at random from the ranges given in Table 1 in each simulation at each site, and their values exert a strong control on the quality of the fit.

[30] As a control, we first apply the landscape evolution model to the representative profile from the Gabilan Mesa site. In this landscape, soil creep and fluvial incision are the most important geomorphic processes and there is no evidence of landslide activity. The representative profile (Figures $6 \mathrm{a}$ and $6 \mathrm{~b}$ ) reflects this since the slope increases linearly with distance from the divide over the upper half of the profile, as predicted for soil creep, and then decreases smoothly over the lower half of the profile, as predicted by the stream power model. Our best fit modeled profile matches the observed profile well and is especially sensitive to $D^{*}$ and $K^{*}$, as shown by the sharp minima in Figures 7 a and $7 \mathrm{c}$. As expected for a site with no earthflow activity, results are not sensitive to $V^{*}$, as long as it is less than $\sim 0.1$, as shown by the broad, flat minimum in Figure $7 \mathrm{~b}$.

[31] We next apply our model to the Eel River site underlain by the sandstone lithology where there are only a

Table 1. Parameter Values That Generate the Best Fit Between Modeled and Observed Hillslope Profiles for the Gabilan Mesa and Eel River Study Sites and the Ranges of Parameters Sampled ${ }^{\mathrm{a}}$

\begin{tabular}{|c|c|c|c|c|c|c|}
\hline \multirow[b]{2}{*}{ Free Parameter } & \multicolumn{3}{|c|}{ Best Fit Values } & \multicolumn{3}{|c|}{ Range } \\
\hline & Gab. & San. & Mel. & Gab. & San. & Mel. \\
\hline$D^{*}$ & 1.3 & $4.2 \times 10^{-2}$ & $7.7 \times 10^{-3}$ & $1 \times 10^{-1}-1 \times 10^{1}$ & $1 \times 10^{-3}-1 \times 10^{0}$ & $1 \times 10^{-3}-1 \times 10^{1}$ \\
\hline$V^{*}$ & $4.3 \times 10^{-2}$ & 9.0 & $1.7 \times 10^{2}$ & $1 \times 10^{-6}-1 \times 10^{2}$ & $1 \times 10^{-1}-1 \times 10^{3}$ & $1 \times 10^{1}-1 \times 10^{4}$ \\
\hline$K^{*}$ & 10.3 & 26.9 & 5.7 & $1 \times 10^{0}-1 \times 10^{2}$ & $1 \times 10^{-1}-1 \times 10^{2}$ & $1 \times 10^{-1}-1 \times 10^{3}$ \\
\hline$x_{c}$ & 0.52 & 0.12 & 0.11 & $0.4-0.6$ & $0.01-0.3$ & $0.01-0.3$ \\
\hline$h m / n$ & $0.63^{\mathrm{b}}$ & 0.10 & 0.21 & $0.63^{\mathrm{b}}$ & $0.1-2.0$ & $0.1-2.0$ \\
\hline RMS error & $2.7 \times 10^{-3}$ & $3.5 \times 10^{-3}$ & $3.0 \times 10^{-3}$ & & & \\
\hline
\end{tabular}

${ }^{\mathrm{a}} \mathrm{Gab} .=$ Gabilan Mesa (Figure 5a), San. = Eel River sandstone lithology (Figure 5b), and Mel. = Eel River mélange lithology (Figure 5c).

${ }^{\mathrm{b}}$ Denotes values that were held constant in determining the best fit profile at that site. 
few small $\left(<0.025 \mathrm{~km}^{2}\right)$, isolated patches of historic earthflow activity [Mackey and Roering, 2011]. The fluvial network at this site is much less organized than at the Gabilan Mesa site, but the gullies are more established than at the mélange site, as evidenced by the subtly concave profile over the lower $\sim 90 \%$ of the hillslope (Figures $6 \mathrm{c}$ and $6 \mathrm{~d}$ ). Our best fit modeled profile matches this observed profile and is most sensitive to $V^{*}$ and $K^{*}$ (Figures $7 \mathrm{f}$ and $7 \mathrm{~g}$ ). The misfit is relatively insensitive to $D^{*}$ (Figure 7e) as long as it is less than $\sim 0.1$, indicating that soil creep is not important in setting the long-term profile form at this location compared to earthflow and gully processes. Small values of $h m / n$ also tend to result in a better fit (Figure 7i), indicating that gully incision at this site does not depend strongly on drainage area, but instead depends strongly on local topographic gradient (equation (2)).

[32] Finally, we apply our model to the Eel River site underlain by Franciscan mélange where several large (up to $\sim 0.5 \mathrm{~km}^{2}$ ) earthflows are active and nearly $10 \%$ of the surrounding landscape area contains historically active earthflows [Mackey and Roering, 2011]. Here, the gully network consists of many small, often disconnected segments, and the average profile is slightly convex (Figures 6e and 6f), both of which suggest the importance of earthflow processes. Our best fit modeled profile also matches the observed profile well at this site. The misfit is most sensitive to $V^{*}$, and a narrow range of values for $K^{*}$ fit the data approximately equally well (Figures $7 \mathrm{k}$ and 71 ). Similar to the Eel River sandstone profiles, the misfit is not sensitive to $D^{*}$ as long as it is less than $\sim 0.1$ (Figure 7j). Small values of $h m / n$ also tend to result in a better fit (Figure 7n), but the minimum is not as well defined as at the sandstone site, perhaps because the earthflow term exerts a much stronger control on profile form at this site.

\subsection{Spatial Erosion Patterns}

[33] To highlight spatial variations in the modeled geomorphic processes, we substitute these best fit parameter values (Table 1) back into equation (13) and calculate the contribution of each transport process to the dimensionless rate of change of the land surface elevation, $\partial z^{*} / \partial t^{*}$, at each point along the profile (Figure 8). A negative contribution to $\partial z^{*} / \partial t^{*}$ at a given point indicates that the particular process lowers the land surface elevation (erosion), while a positive contribution indicates that the process raises the land surface elevation (deposition). Because we solve for steady state topographic profiles, the contributions of the soil creep, earthflow, and gully terms must sum to equal the long-term erosion rate, $-\rho^{*}$, at every point along the profile. The values of $D^{*}, V^{*}$, and $K^{*}$ set the profile-averaged magnitude of each geomorphic process, but the local topographic gradient, curvature, and distance from the drainage divide modulate the intensity and sign of each process along the profile.

[34] For the Gabilan Mesa profile (Figure 8a), only soil creep and fluvial incision contribute to the steady state topographic form. When $x^{*}<x_{c}{ }^{*}$, only soil creep transports sediment, so the steady state profile attains a convex form, allowing soil creep alone to lower the land surface elevation at the long-term uplift rate. When $x^{*} \geq x_{c}{ }^{*}$, fluvial incision also plays a role in balancing uplift and contributes to lowering the land surface elevation. Because this segment of the profile is concave, the soil creep term is positive and contributes to raising the land surface elevation, so the stream power term must lower the land surface elevation more rapidly than the long-term uplift rate to keep pace. This effect is especially apparent when $x^{*}$ is just greater than $x_{c}{ }^{*}$, where the profile has the highest concavity as well as a high topographic gradient. The sharp step in process rates at $x_{c}{ }^{*}$ results from the model's assumption that the drainage area threshold for channel incision is fixed at $x_{c}{ }^{*}$ over time. In the field, the position of the channel head likely fluctuates over time [Dietrich and Dunne, 1993], which would smooth this process transition when temporally averaged. Earthflows are not present at this site and do not significantly affect the modeled steady state profile form.

[35] At the sandstone site in the Eel River study area (Figure $8 \mathrm{~b}$ ), earthflow deformation and gully incision exert the strongest controls on topographic form. Soil creep plays a minor role in smoothing the drainage divide and nearly keeps pace with the uplift rate there, but contributes negligibly to changing the land surface elevation on the remainder of the quasi-planar hillslope. Instead, when $x^{*}<x_{c}{ }^{*}$, the earthflow term becomes increasingly important in lowering the land surface elevation with increasing $x^{*}$ and approximately keeps pace with uplift near $x_{c}{ }^{*}$. However, at $x_{c}{ }^{*}$ the profile abruptly becomes concave and has a high topographic gradient until $x^{*} \sim 0.3$. Over this range of $x^{*}$, the gully term lowers the land surface elevation more quickly than the longterm uplift rate because of the high, but decreasing, topographic gradient, and the earthflow term contributes to raising the land surface elevation because of the high profile concavity. The remaining section of the profile becomes approximately planar, and the gully term alone nearly keeps pace with uplift, reflecting the low $\mathrm{hm}$ (drainage area exponent) to $n$ (slope exponent) ratio of the best fit model result. Despite its sensitivity to the topographic gradient, the earthflow term does not contribute to changing the land surface elevation over this section of the profile because the gradient is remarkably uniform, resulting in a steady flux of earthflow material downslope.

[36] At the mélange site in the Eel River study area (Figure 8c), earthflows and gullies again strongly control the topographic form, with soil creep playing only a minor role in lowering the drainage divide. As at the sandstone site, the earthflow term is effective at lowering the land surface elevation when $x^{*}<x_{c}{ }^{*}$ and keeps pace with uplift near $x_{c}{ }^{*}$. However, when $x^{*}>x_{c}{ }^{*}$, the modeled profile is still convex at this site, so the earthflow term continues to contribute to lowering the land surface elevation, although at a much slower rate. The gully incision term contributes to lowering the land surface elevation over this section of the profile as well, but its magnitude does not exceed the long-term uplift rate as it did at the other two sites. As $x^{*} \rightarrow 1$, the profile becomes nearly planar, and the gully term alone is able to keep pace with uplift while the earthflow term transports a steady flux of sediment.

[37] Although along-profile variations in the sign and magnitude of the modeled geomorphic processes are different between the two Eel River sites, they both fit well with observed characteristics of earthflows. Earthflows typically have an upper source area that feeds sediment into a long, narrow transport zone, which ends in a bulbous toe at the foot of a hillslope [Kelsey, 1978; Keefer and Johnson, 1983; Cruden and Varnes, 1996; Baum et al., 2004]. Earthflow 


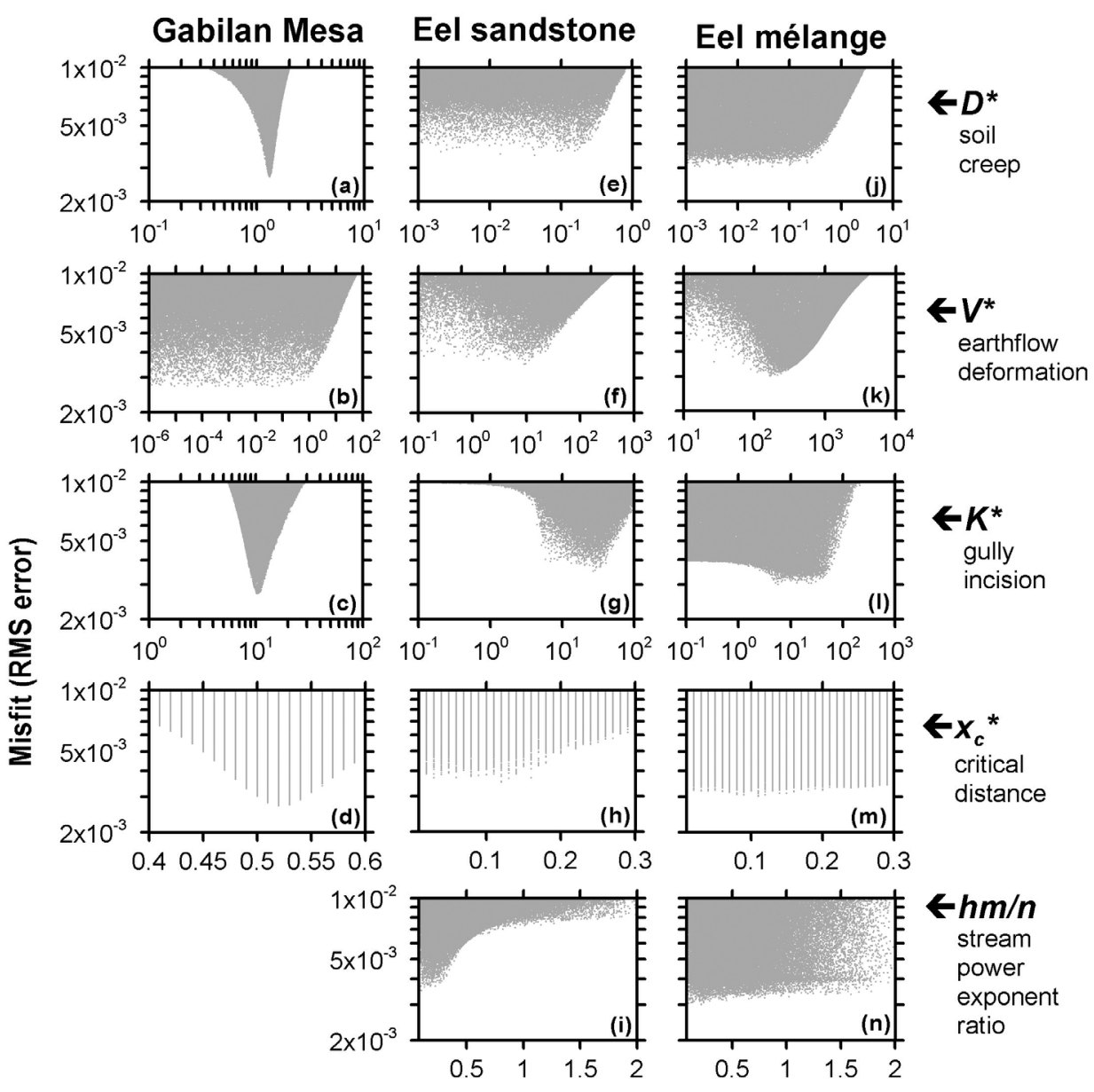

Figure 7. Misfit versus the landscape evolution model's free parameters at each of the study sites. Each point represents a steady state solution to equation (11) generated with a random combination of parameters from the ranges given in Table 1 . The minimum of each point cloud defines the best modelgenerated profile.

source areas in the study area often occur just below drainage divides, and our model predicts that earthflows at both the sandstone and mélange sites substantially lower the land surface elevation near the drainage divide over the long term. Transport zones in the study area extend most of the length of hillslopes and tend to transport a roughly steady flux of sediment by plug flow [Mackey et al., 2009]. Our model captures this behavior well at the middle and lower sections of the profiles, where the earthflow term contributes negligibly to changing the land surface elevation relative to the gully term. However, at the sandstone site, the model predicts a small region where earthflows substantially contribute to raising the land surface elevation just after $x_{c}{ }^{*}$ instead of transitioning smoothly into the transport zone regime. As modeled, this indicates a small zone at the lower edge of the earthflow source area where earthflows are inefficient at transporting sediment because of the rapidly decreasing topographic gradient. This effect is not present in the modeled mélange profile because it is convex near $x_{c}{ }^{*}$, suggesting that the more vigorous earthflow activity at this site can efficiently transport material from source to transport zones. Some bulbous earthflow toes are present in the study area where an earthflow transports sediment onto a flat part of terrain, but rivers flowing along the base of hillslopes often truncate earthflows before they form distinct depositional toes. Our model simulates hillslope processes and does not include riverbank processes, so the profiles end just before reaching a hillslope-bounding river, and the model results are therefore relevant to the truncated earthflow transport zones common in the study area.

\subsection{Long-Term Process Rates}

[38] Our LEM results also provide estimates of the longterm average sediment flux along each study site's representative profile that is due to the modeled geomorphic processes. To determine average fluxes, we numerically integrate the curves in Figure 8, multiply by an estimated uplift rate, $U$, and the mean profile length, $\ell$, divide by the density ratio, $\rho^{*}$, and then average over the length of the profile. At the Gabilan Mesa site, we estimate a modest uplift rate of $0.3 \mathrm{~mm} \mathrm{yr}^{-1}$ and at the Eel River site assume a faster rate of $1 \mathrm{~mm} \mathrm{yr}^{-1}$ (section 2). Since the magnitude of the sediment flux due to each modeled process scales linearly with $U$, different estimates of $U$ give different total fluxes, but each process contributes the same proportion to the total flux. The uncertainty in the magnitude of the estimated fluxes is also directly proportional to the uncertainty in $U$. Mean profile lengths are 171, 1287, and $1329 \mathrm{~m}$ 


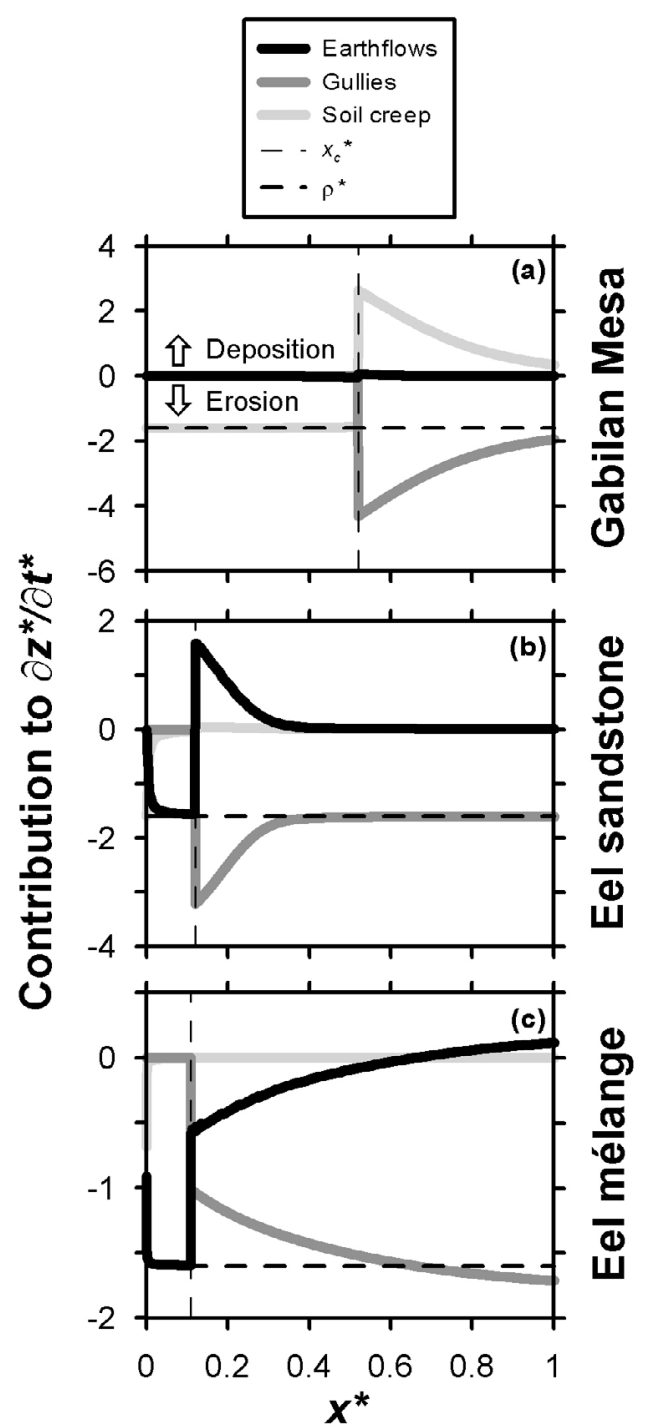

Figure 8. Contributions of each modeled geomorphic process to $\partial z^{*} / \partial t^{*}$ at each point along the best fit profiles from the three study sites. The light grey line shows the contribution from the soil creep term, the medium grey shows the gully incision term, and the black shows the earthflow term. At every point along the profile these three terms sum to the long-term nondimensional erosion rate, $-\rho^{*}$, shown as the horizontal dashed line.

at the Gabilan Mesa, Eel River sandstone, and Eel River mélange sites, respectively.

[39] Table 2 lists the average sediment fluxes per unit contour width due to each process at each site predicted by the landscape evolution model. The magnitude of any one of these fluxes is only as precise as the uplift rate, but we report all the fluxes as though uplift rate is known precisely in order to highlight the proportional contributions of each process to the sediment flux at each site. In the Gabilan Mesa, sediment flux along the representative profile is approximately balanced between soil creep and fluvial incision, with soil creep on average transporting 54\% of the sediment and fluvial processes transporting $46 \%$. We emphasize that this result is particular to our chosen first-order valley profiles and that the balance of sediment fluxes would tip much more in favor of soil creep on hillslope-only profiles or toward fluvial processes on profiles including more of the fluvial network. In the Eel River sandstone lithology, gully processes become very important in transporting sediment along the profile and, on average, account for $\sim 94 \%$ of the sediment flux. In terms of volume of sediment transported, earthflows are of minor importance at this site, transporting just $4 \%$ of the sediment, while soil creep transports the remaining $2 \%$. However, smaller values of $D^{*}$ also allow the model to match the observed profile well at this site, so this $2 \%$ soil creep contribution is a maximum value. Although earthflow motion does not deliver much sediment to the channel network at this site, it is important on the upper hillslope in allowing the model to match the observed profile. In the Eel River mélange lithology, gullies also transport the majority of the sediment (69\%), but earthflows contribute a substantial 31\% to the average sediment flux. This finding is similar to that of Kelsey [1978] in the nearby Van Duzen River basin, where earthflow motion and gully erosion from earthflows each supplies about $50 \%$ of the sediment to rivers truncating earthflow toes, although on average the earthflows in that study move more rapidly and are deeper than those in our Eel River site.

[40] The absolute magnitude of our modeled earthflow flux, $q_{e}=2.1 \times 10^{-1} \mathrm{~m}^{2} \mathrm{yr}^{-1}$, is consistent with observations that earthflows in the Eel River mélange lithology are typically several meters deep, move $\sim 1 \mathrm{~m} \mathrm{yr}^{-1}$, and historically occur in $\sim 10 \%$ of the terrain at a given time [Mackey and Roering, 2011]. However, because this estimate depends on the uplift rate, which we do not know precisely at this site, we consider it an order of magnitude estimation. That this flux is of the same order as the modern flux suggests that earthflows have been active at similar rates over the $>10^{3}$ year timescales encapsulated by the averaged topographic profiles used in this study.

\subsection{Model-Predicted Steady State Hillslope Relief}

[41] To place the predictions of our model in a wider spatial and temporal context, we calculate curves of steady state, dimensionless hillslope relief (maximum hillslope elevation divided by length, or the average topographic gradient) over a range of rock uplift rates while varying two key parameters that describe earthflow behavior, $V^{*}$ and $p$ (Figure 9). Although the value of $p$ does not exert a strong

Table 2. Long-Term Average Sediment Fluxes per Unit Contour Width Due to Each Geomorphic Process at Each Site Predicted by the Best Fit Modeled Profiles ${ }^{\mathrm{a}}$

\begin{tabular}{lccc}
\hline Mean Sediment Flux & Gab. & San. & Mel. \\
\hline Soil creep, $q_{s}\left(\mathrm{~m}^{2} \mathrm{yr}^{-1}\right)$ & $1.4 \times 10^{-2}(54 \%)$ & $9.8 \times 10^{-3}(2 \%)$ & $1.4 \times 10^{-3}(0 \%)$ \\
Earthflow, $q_{e}\left(\mathrm{~m}^{2} \mathrm{yr}^{-1}\right)$ & $2.1 \times 10^{-5}(0 \%)$ & $2.8 \times 10^{-2}(4 \%)$ & $2.1 \times 10^{-1}(31 \%)$ \\
Gully, $q_{g}\left(\mathrm{~m}^{2} \mathrm{yr}^{-1}\right)$ & $1.2 \times 10^{-2}(46 \%)$ & $6.1 \times 10^{-1}(94 \%)$ & $4.6 \times 10^{-1}(69 \%)$ \\
\hline
\end{tabular}

${ }^{\mathrm{a}}$ Gab. = Gabilan Mesa (Figure 5a), San. = Eel River sandstone lithology (Figure 5b), and Mel. = Eel River mélange lithology (Figure 5c). 


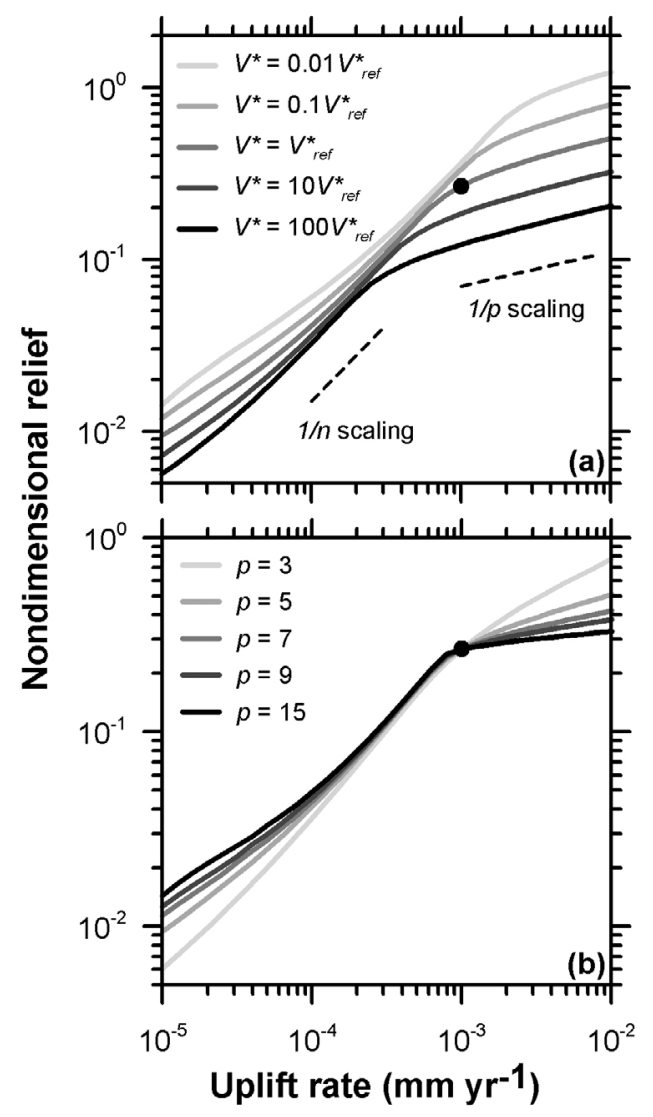

Figure 9. Model-predicted hillslope relief (normalized by hillslope length) as a function of uplift rate for varying magnitudes of (a) $V^{*}$ with $p=5$ and (b) $p$. The reference profile, indicated by the black dot, is the best fit modeled profile at the Eel mélange site with $U=1 \mathrm{~mm} \mathrm{yr}^{-1}$.

control on our best fit profiles, it does dramatically influence the model's theoretical predictions of how steady state relief scales with uplift rate. Changing $V^{*}$ relative to $D^{*}$ and $K^{*}$ affects the overall magnitude of earthflow processes and, according to equation (12c), accommodates changes in earthflow characteristic depth, $H$, bulk density, $\rho_{e}$, or the constant in the non-Newtonian flow law, $a$. Changes in the magnitude of $V^{*}$ may therefore reflect changes in climate since the presence of more or less water within an earthflow likely affects all three of these parameters. The highly nonlinear influence of $H$ on $V^{*}$ implies that changes in earthflow thickness most strongly affect the magnitude of $V^{*}$, so deeper weathering, perhaps due to variable precipitation or lowering of the water table, may be the most effective way to increase the overall magnitude of earthflow activity. Changing $p$ affects the nonlinearity of the flow law (equation (6)) and therefore whether earthflows behave more viscously or plastically in the long term.

[42] To generate earthflow-driven, steady state relief versus erosion rate curves (Figure 9), we first take the best fit profile from the Eel River mélange site as a reference state with an uplift rate of $1 \mathrm{~mm} \mathrm{yr}^{-1}$ and a dimensionless hillslope relief of 0.27 . We then simulate changes in the uplift rate by proportionately changing the magnitudes of $D^{*}, V^{*}$, and $K^{*}$, which results in a relief-uplift rate curve for the Eel River mélange reference state. Next, we vary $V^{*}$ by 4 orders of magnitude above and below the reference state and similarly simulate changes in uplift rate using these increased or decreased values of $V^{*}$. This results in a suite of relief-uplift rate curves for different values of $V^{*}$ (Figure 9a). We also calculate how varying the landslide rheology parameter, $p$, influences the relationship between relief and uplift rate. Again using the Eel River mélange profile, we first vary $p$ above and below the reference value and determine the best fit $V^{*}$ while leaving all other parameters constant. This produces several nearly indistinguishable best fit modeled profiles with an average gradient and relief similar to the observed profile (Figures 6e and 6f). We then generate an additional suite of relief-uplift rate curves by proportionally varying $D^{*}, V^{*}$, and $K^{*}$.

[43] Figures 9a and 9b illustrate two distinct regimes over which dimensionless relief increases with uplift rate. At low uplift rates, relief increases relatively rapidly with uplift rate, and modeled profiles in this regime are highly concave, indicating that the stream power term most influences topographic form. This concavity is possible because the stream power term depends on $x^{*}$ in addition to the local topographic derivative and is therefore able to incise even as topographic gradients become low. Relief increases approximately as $1 / n$ in this regime, as predicted by equation (13) with $D^{*}, V^{*}=0$. However, at extremely low uplift rates the relief scaling deviates slightly from this trend because the stream power term reduces the topographic gradient to near zero over most of the lower profile, where $x^{*} \geq x_{c}{ }^{*}$. For uplift rates similar to that of the reference state, relief begins to increase less rapidly as the modeled profiles transition into a more earthflow-dominated regime. The magnitudes of $V^{*}$ and $p$ affect the details of this high uplift rate regime by altering modeled earthflow behavior. Increases in $V^{*}$ alone (Figure 9a), with $p=5$ as in the Eel River mélange reference state, cause a decrease in hillslope relief across the full range of simulated uplift rates and also shift the transition to the earthflowdominated regime to lower uplift rates. In other words, as earthflows become more effective at transporting sediment, they require smaller topographic gradients to keep pace with uplift and exert a dominant control on topographic form at relatively modest uplift rates. Increases in $p$ cause hillslope relief to increase less rapidly with uplift rate in the earthflowdominated regime, and relief approaches a threshold value as $p \rightarrow \infty$ and the rheology becomes completely plastic. Relief increases approximately as $1 / p$ in this regime as predicted by equation (13) when $D^{*}, K^{*}=0$. The tendency for relief to become insensitive to uplift rate as $p$ increases is consistent with the idea of threshold hillslopes resulting from finite rock mass strength [Carson and Petley, 1970; Schmidt and Montgomery, 1995; Burbank et al., 1996]. However, our landscape evolution model predicts that if landslides have a viscous component to their deformation and behave more as a plug-type flow, hillslope relief, or the average topographic gradient, may continue to be an indicator of uplift rate even with strong tectonic forcing.

\section{Discussion}

[44] In this paper, we propose a mechanistic geomorphic transport law for deep-seated earthflows that is consistent with observed topographic profiles and geomorphic process rates in the study areas. By focusing on average hillslope 
profiles, with lengths of hundreds of meters to kilometers and geomorphically significant timescales of $>10^{3}$ years, our results offer several advantages over both long-term, rangescale studies and short-term, site-specific earthflow studies. For example, our slope-area analysis (Figure 3) demonstrates that the topographic gradient in earthflow-prone terrain tends to slowly decrease over a wide range of drainage areas up to $\sim 10^{6} \mathrm{~m}^{2}$, suggesting that a threshold slope approximation, as is commonly employed in rangescale landscape evolution models [Howard, 1994; Tucker and Slingerland, 1994; Tucker and Bras, 1998; van der Beek et al., 1999], would not adequately capture the topographic trends in the study area. Furthermore, applying a threshold slope model to the study area would not capture the subtle differences in profile curvature (Figure 6) that strongly control both spatial patterns (Figure 8) and average rates (Table 2) of earthflow sediment transport in our model. On the other hand, at shorter spatial and temporal scales over which earthflow motion is typically monitored, sediment transport is highly variable, and measured rates from an individual earthflow may not be representative of longer-term average rates. By using topographic form to infer relative process rates, our model averages over this short-term variability and yields relative rates specifically relevant to the observed topography. We emphasize that our estimate of $V^{*}$ also represents a landscape-scale, long-term average, although site-specific studies and laboratory experiments may constrain reasonable values for the dimensional parameters contained in $V^{*}$, such as $a$ and $p$ in the nonNewtonian flow law.

[45] Our Monte Carlo simulations show that the magnitudes of $D^{*}, V^{*}$, and $K^{*}$ dictate the morphology of hillslopes at the study sites, but the behavior of the model with respect to $h m / n$ and $p$ reveals details about the mechanisms of each modeled geomorphic process. At both Eel River study sites, lower values of $\mathrm{hm} / \mathrm{n}$ result in better matches between modeled and observed profiles, indicating that gully incision depends only weakly on distance from the drainage divide. This could result from low values of $h$ or $m$ or a high value of $n$. We determined that $h=1.25 \pm 0.01$ (95\% confidence) by plotting drainage area versus downstream distance for eight major gullies spanning the Eel River mélange hillslope. This value is significantly less than both $h=2$, which would indicate self-similar scaling, and Hack's [1957] value of $h=1.67$, indicating that drainage area increases less rapidly with downstream distance than in many other settings. In the stream power model, $m$ depends on the exponents describing the dependence of incision rate on shear stress, the dependence of channel width on discharge, and the dependence of discharge on drainage area [Whipple and Tucker, 1999]. Our small best fit values of $h \mathrm{~m} / \mathrm{n}$ could therefore also result from a weak dependence of incision rate on shear stress, a strong dependence of channel width on discharge, or a weak dependence of discharge on drainage area. Of these options, we expect the first to be unlikely since our model predicts high values of $n$ at the Eel River sandstone site and $n$ reflects only the dependence of incision rate on shear stress [Whipple and Tucker, 1999]. Instead, we find it more likely that channel width depends strongly on discharge, perhaps because of a more rapid increase in channel width with downstream distance compared with alluvial channels, as found by Snyder et al. [2000] for small catchments near the study area. Also, it may be that discharge increases slowly with drainage area at the study sites, possibly because of ecological factors such as spatial variations in evapotranspiration.

[46] Interestingly, the insensitivity of our model results to $p$, so long as it yields a plug-like flow, implies that the specific style of earthflow deformation or sliding is less important than the overall magnitude of the depth-averaged earthflow flux in generating the observed profiles in the study area. Within the model, this insensitivity may arise from the dependence of $V^{*}$ on $p$ (equation (12c)), which allows many combinations of these two parameters to match the observed profiles equally well. Also, as $p$ increases, the rheology of the modeled earthflows rapidly becomes more plastic so that further increases in $p$ do not substantially change the shape of the resulting steady state profile. Our method for choosing representative profiles may also contribute to this insensitivity by averaging over much of the spatial and temporal variabilities in earthflow behavior present at each site. For example, the Eel River mélange site (Figure 5c) contains several active earthflows with different sizes, possibly different failure mechanisms, and different movement rates, but our model seeks to capture only the first-order, long-term form of the landscape by matching an averaged, representative profile. Although this technique does not reveal much information about $p$ at the study sites, it does imply that earthflows transport material in a plug-flow fashion, and it may provide information about other earthflow properties relevant to long-term landscape evolution such as the characteristic depth $H$, flow law constant $a$, or earthflow bulk density $\rho_{e}$, according to equation (12c) and given independent estimates of some of these parameters.

[47] Despite this insensitivity to $p$, and therefore to the specifics of earthflow failure mechanisms, we emphasize the importance of explicitly connecting geomorphic transport laws to relevant geomorphic processes. Other mathematical expressions can produce low-gradient, near-planar hillslopes with convex ridgetops similar to those produced by our equation (7) for earthflow flux, but do not lead to insights into earthflow behavior. For example, an equation in which sediment flux increases nonlinearly with the topographic gradient and approaches infinity at some critical slope value produces a similar hillslope form [Howard, 1994; Roering et al., 1999], but is rooted in force and energy considerations of surface particles being disturbed by various biological and physical processes [Roering et al., 1999]. More recently, models of Tucker and Bradley [2010] and FoufoulaGeorgiou et al. [2010] produce relatively planar hillslopes by emphasizing nonlocal transport, in which a surface disturbance can move individual sediment grains distances comparable to the hillslope length scale. We could potentially compare our earthflow profiles with any of these models, but such an endeavor would not reveal much about the behavior of slow-moving earthflows with a depth-dependent sediment flux.

[48] Our model formulation allows some speculation about the effects of changes in climatic forcing on long-term landscape evolution in earthflow-prone terrain. Changes in precipitation affect the parameters describing soil creep (equation (1)) [Fernandes and Dietrich, 1997; Tucker and Bras, 1998; Perron et al., 2009] and stream power (equation (2)) [Tucker and Slingerland, 1997; Whipple, 
2001] through changes in vegetation, for example. However, within the framework of our model, changes in precipitation probably most strongly affect the magnitude of the earthflow flux (equation (7)) because of its highly nonlinear dependence on earthflow thickness $H$. As described in section 3.3, the position of the weathering front sets the depth of mobile earthflow material. In fine-grained, argillaceous mudstones, such as the Franciscan mélange underlying much of the study area, cycles of wetting and drying often drive weathering [Ollier, 1969; Franklin and Chandra, 1972; Matsukura and Mizuno, 1986; Stephenson and Kirk, 2000] so that the position of the weathering front should approximately track the position of the groundwater table, as observed by Rempe et al. [2010] in a lithology similar to that of the study area. In this way, we suggest that the long-term depth of earthflow activity should be inversely related to the amount of precipitation. Sustained wetter climatic periods would ultimately result in thinner earthflows, so the terrain in our model would steepen, causing the depth-averaged velocity of earthflows to increase in order to accommodate a given sediment flux. Conversely, drier climatic periods would lead to thicker earthflows, so gentler slopes in the model would allow slower earthflow failures to accommodate a given flux of sediment. Changes in the frequency and magnitude of earthflow occurrence could also result from changes in average earthflow depth, but our model does not make any quantitative predictions about these changes because it does not explicitly include stochastic earthflow behavior. This relationship between earthflow depth and climate may in part explain observations of more earthflows on dry, south-facing slopes in and near the study area [Kelsey, 1978; Mackey and Roering, 2011]. In other words, the limited depth of weathering may inhibit earthflow activity on the wetter north-facing slopes.

[49] Finally, we suggest that our method for including deep-seated earthflows in a model using an expression for a depth-dependent sediment flux may be adaptable to other types of slope failures. In landscapes with more competent bedrock than in the study site, the typical spacing of weak sedimentary layers or joints, for example, could set the failure depth, which would vary spatially and temporally as other geomorphic and tectonic processes modify the landscape. Incorporating this depth information into an expression for landslide velocity would then determine the flux due to the modeled landslide process. We choose a nonNewtonian flow law to determine the landslide flux in the study area because it captures the general behavior of earthflows, but different rheologies or frictional properties of a failure surface, for example, could determine rates of landslide motion in other landscapes. We emphasize that including such simplified treatments of landslide behavior in landscape evolution models can lead to new insights into spatial and temporal patterns of erosion and feedbacks between geomorphic processes.

\section{Conclusions}

[50] This study presented a mathematical model that captured the general characteristics of a deep-seated earthflowprone landscape along the Eel River, northern California. By combining expressions for sediment fluxes or incision rates due to soil creep, earthflow, and fluvial processes, we first derived an equation to describe the change in the land surface elevation with time along a hillslope profile. Steady state profiles modeled using this equation matched representative profiles from sites with varying levels of historic earthflow activity. The magnitude of a nondimensional number describing the intensity of earthflow processes based on a non-Newtonian flow rheology tracked the level of historic earthflow activity well. Using best fit modeled profiles, we then determined the contribution of each modeled geomorphic process to changing the land surface elevation at each point along the profile. Modeled earthflows contributed substantially to lowering the land surface elevation on the upper hillslopes and transported an approximately steady flux of sediment on middle to lower hillslopes, consistent with observations of earthflow collection zones and transport zones, respectively, in the Eel River study area. The best fit profiles also provided estimates for the long-term average sediment flux that is due to each modeled geomorphic process, with modeled earthflows contributing the highest flux at the site with the most historic earthflow activity. The magnitude of this flux, of the order of $10^{-1} \mathrm{~m}^{2} \mathrm{yr}^{-1}$, is consistent with modern earthflow movement rates at that site, but modeled gullies incising the earthflow surface transported the majority of sediment along the profile. We also generated theoretical curves of steady state hillslope relief versus uplift rate, which indicated that relief increases nonlinearly with uplift rate in earthflow-prone landscapes. These results indicated that topographic metrics such as mean hillslope angle, if known precisely, may record uplift rate in earthflow-prone landscapes even at high uplift rates where threshold slope processes normally limit further topographic development.

[51] We demonstrated that incorporating a geomorphic transport law for deep-seated earthflow processes into a landscape evolution model can yield valuable information about spatial and temporal patterns of sediment transport. In doing so, we addressed a gap in landscape evolution modeling between long-term ( $>10^{6}$ years), range-scale studies and short-term $\left(<10^{2}\right.$ years $)$, hillslope-scale studies. Future landscape evolution modeling studies potentially have much to gain by focusing on interactions among simple expressions for various geomorphic processes, especially deepseated landsliding.

[52] Acknowledgments. This work was supported by a NSF Graduate Research Fellowship to AMB and NSF award EAR-OCE-0841111 to J.J.R. A.M.B. thanks Alan Rempel for discussions about mathematical and numerical methods, and Ben Mackey, Harvey Kelsey, Noah Finnegan, and others for various earthflow and numerical modeling discussions. Detailed reviews provided by Greg Tucker and two anonymous reviewers, as well as remarks from the associate editor, substantially improved this manuscript.

\section{References}

Ahnert, F. (1976), Brief description of a comprehensive three-dimensional process-response model of landform development, Z. Geomorphol., 25, Suppl., 29-49.

Ahnert, F. (1977), Some comments on the quantitative formulation of geomorphological processes in a theoretical model, Earth Surf. Processes, 2, 191-201, doi:10.1002/esp.3290020211.

Ahnert, F. (1987), Process-response models of denudation at different spatial scales, Catena, 10, Suppl., 31-50.

Barnes, H. A., J. F. Hutton, and K. Walters (1989), An Introduction to Rheology, Elsevier, Amsterdam. 
Baum, R. L., W. Savage, and J. Wasowski (2004), Mechanics of earthflows, Proceedings of the International Workshop on Occurence and Mechanisms of Flow-Like Landslides in Natural Slopes and Earthfills, edited by L. Picarelli, pp.185-190, Patron Ed., Bologna, Italy.

Bovis, M. J., and P. Jones (1992), Holocene history of earthflow mass movements in south-central British Columbia-The influence of hydroclimatic changes, Can. J. Earth Sci., 29, 1746-1755, doi:10.1139/e92-137.

Brunetti, M. T., F. Guzzetti, and M. Rossi (2009), Probability distributions of landslide volumes, Nonlinear Processes Geophys., 16, 179-188, doi:10.5194/npg-16-179-2009.

Brunsden, D. (1984), Mudslides, in Slope Instability, edited by D. Brunsden and D. B. Prior, pp. 363-418, John Wiley, Chichester, U. K

Burbank, D. W., J. Leland, E. Fielding, R. S. Anderson, N. Brozovic, M. R. Reid, and C. Duncan (1996), Bedrock incision, rock uplift and threshold hillslopes in the northwestern Himalayas, Nature, 379, 505-510, doi:10.1038/379505a0.

Carson, M. A., and D. J. Petley (1970), The existence of threshold hillslopes in the denudation of landscapes, Trans. Inst. Brit. Geogr., 49, 71-95.

Christensen, M. N. (1965), Late Cenozoic deformation in the central coast ranges of California, Geol. Soc. Am. Bull., 76, 1105-1124, doi:10.1130/ 0016-7606(1965)76[1105:LCDITC]2.0.CO;2.

Coe, J. A., W. L. Ellis, J. W. Godt, W. Z. Savage, J. E. Savage, J. A. Michael, J. D. Kibler, P. S. Powers, D. J. Lidke, and S. Debray (2003), Seasonal movement of the Slumgullion landslide determined from Global Positioning System surveys and field instrumentation, July 1998-March 2002, Eng. Geol., 68, 67-101, doi:10.1016/S00137952(02)00199-0

Crozier, M. J. (1968), Earthflows and related environmental factors of Eastern Otago, N. Z. J. Hydrol., 7, 4-12.

Cruden, D. M., and J. Krahn (1973), A reexamination of the geology of the Frank Slide, Can. Geotech. J., 10, 581-591, doi:10.1139/t73-054.

Cruden, D. M., and D. J. Varnes (1996), Landslide types and processes, in Landslides Investigation and Mitigation, edited by A. K. Turner and R. L. Schuster, pp. 36-75, Natl. Acad. Press, Washington, D. C.

Culling, W. E. H. (1960), Analytical theory of erosion, Geology, 68, 336-344, doi:10.1086/626663.

Davis, W. M. (1892), The convex profile of bad-land divides, Science, 20, 245, doi:10.1126/science.ns-20.508.245.

Densmore, A. L., M. A. Ellis, and R. S. Anderson (1998), Landsliding and the evolution of normal-fault-bounded mountains, J. Geophys. Res. 103(B7), 15,203-15,219, doi:10.1029/98JB00510.

Dietrich, W. E., and T. Dunne (1993), The channel head, in Channel Network Hydrology, edited by K. Beven and M. J. Kirkby, pp. 175-219, John Wiley, New York.

Dietrich, W. E., and J. T. Perron (2006), The search for a topographic signature of life, Nature, 439, 411-418, doi:10.1038/nature04452.

Dietrich, W. E., D. G. Bellugi, L. S. Sklar, J. D. Stock, A. M. Heimsath, and J. J. Roering (2003), Geomorphic transport laws for predicting landscape form and dynamics, in Prediction in Geomorphology, Geophys. Monogr. Ser, vol. 135, edited by P. R. Wilcock and R. M. Iverson, pp. 103-132, AGU, Washington, D. C.

Dumitru, T. A. (1991), Major Quaternary uplift along the northernmost San Andreas fault, King Range, northwestern California, Geology, 19 526-529, doi:10.1130/0091-7613(1991)019<0526:MQUATN>2.3.CO;2.

Fernandes, N. F., and W. E. Dietrich (1997), Hillslope evolution by diffusive processes: The timescale for equilibrium adjustments, Water Resour Res., 33, 1307-1318, doi:10.1029/97WR00534.

Foufoula-Georgiou, E., V. Ganti, and W. E. Dietrich (2010), A nonlocal theory of sediment transport on hillslopes, J. Geophys. Res., 115, F00A16, doi:10.1029/2009JF001280.

Franklin, J. A., and R. Chandra (1972), The slake-durability test, Int. J. Rock Mech. Min. Sci., 9, 325-328, doi:10.1016/0148-9062(72)90001-0.

Fuller, T. K., L. A. Perg, J. K. Willenbring, and K. Lepper (2009), Field evidence for climate-driven changes in sediment supply leading to strath terrace formation, Geology, 37, 467-470, doi:10.1130/G25487A.1.

Furlong, K. P., and R. Govers (1999), Ephemeral crustal thickening at a triple junction: The Mendocino crustal conveyor, Geology, 27, 127-130, doi:10.1130/0091-7613(1999)027<0127:ECTAAT>2.3.CO;2.

Furlong, K. P., and S. Y. Schwartz (2004), Influence of the Mendocino Triple Junction on the tectonics of coastal California, Annu. Rev. Earth Planet. Sci., 32, 403-433, doi:10.1146/annurev.earth.32.101802.120252.

Gabet, E. J., B. A. Pratt-Sitaula, and D. W. Burbank (2004), Climatic controls on hillslope angle and relief in the Himalayas, Geology, 32, 629-632, doi:10.1130/G20641.1.

Gage, M., and R. D. Black (1979), Slope-stability and geological investigations at Mangatu State Forest, N. Z. For. Serv., Tech. Pap. 66, 37 pp., N.Z. For. Serv., Wellington, New Zealand.
Galehouse, J. S. (1967), Provenance and paleocurrents of the Paso Robles formation, California, Geol. Soc. Am. Bull., 78, 951-978, doi:10.1130/ 0016-7606(1967)78[951:PAPOTP]2.0.CO;2.

Gilbert, G. K. (1877), Geology of the Henry Mountains, U. S. Geographical and Geological Survey of the Rocky Mountain Region, 170 pp., Washington, Govt. Print. Off., Washington, D. C.

Gilbert, G. K. (1909), The convexity of hilltops, J Geol, 17, 344-350.

Guzzetti, F., A. Carrarra, M. Cardinali, and P. Reichenbach (2000), Landslide hazard evaluation: A review of current techniques and their application in a multi-scale study, Central Italy, Geomorphology, 31, 181-216.

Guzzetti, F., F. Ardizzone, M. Cardinali, M. Rossi, and D. Valigi (2009), Landslide volumes and landslide mobilization rates in Umbria, central Italy, Earth Planet. Sci. Lett., 279, 222-229, doi:10.1016/j.eps1.2009.01.005.

Hack, J. T. (1957), Studies of longitudinal stream profiles in Virginia and Maryland, U.S. Geol. Surv. Prof. Pap., 294-B, 97 pp.

Hergarten, S., and H. J. Neugebauer (1998), Self-organized criticality in a landslide model, Geophys. Res. Lett., 25(6), 801-804, doi:10.1029/ 98GL50419.

Hergarten, S., and H. J. Neugebauer (1999), Self-organized criticality in landsliding processes, in Process Modelling and Landform Evolution, Lect. Notes Earth Sci., vol. 78, edited by S. Hergarten and H. J. Neugebauer, pp. 231-249, Springer, Berlin.

Hilley, G. E., R. Bürgmann, A. Ferretti, F. Novali, and F. Rocca (2004), Dynamics of slow-moving landslides from permanent scatterer analysis, Science, 304, 1952-1955, doi:10.1126/science.1098821.

Hovius, N., C. P. Stark, and P. A. Allen (1997), Sediment flux from a mountain belt derived by landslide mapping, Geology, 25, 231-234, doi:10.1130/0091-7613(1997)025<0231:SFFAMB >2.3.CO;2.

Howard, A. D. (1994), A detachment-limited model of drainage basin evolution, Water Resour. Res., 30, 2261-2285, doi:10.1029/94WR00757.

Howard, A. D. (1997), Badland morphology and evolution: Interpretation using a simulation model, Earth Surf. Processes, 22, 211-227, doi:10.1002/(SICI)1096-9837(199703)22:3<211::AID-ESP749>3.0 CO;2-E.

Howard, A. D., and G. Kerby (1983), Channel changes in badlands, Geol. Soc. Am. Bull., 94, 739-752, doi:10.1130/0016-7606(1983)94<739: $\mathrm{CCIB}>2.0 . \mathrm{CO} ; 2$.

Istanbulluoglu, E., and R. L. Bras (2005), Vegetation-modulated landscape evolution: Effects of vegetation on landscape processes, drainage density, and topography, J. Geophys. Res., 110, F02012, doi:10.1029/ 2004JF000249.

Iverson, R. M. (1986a), Dynamics of slow landslides: A theory for timedependent behavior, in Hillslope Processes, edited by A. D. Abrahams, pp. 297-317, Allen and Unwin, Winchester, Mass.

Iverson, R. M. (1986b), Unsteady, nonuniform landslide motion: 1. Theoretical dynamics and the steady datum state, J. Geol., 94, 1-15, doi:10.1086/629006.

Iverson, R. M. (1986c), Unsteady, nonuniform landslide motion: 2. Linearized theory and the kinematics of transient response, J. Geol., 94, 349-364, doi:10.1086/629034.

Iverson, R. M. (2005), Regulation of landslide motion by dilatancy and pore pressure feedback, J. Geophys. Res., 110, F02015, doi:10.1029/ 2004JF000268.

Iverson, R. M., and J. J. Major (1987), Rainfall, groundwater flow, and seasonal movement at Minor Creek landslide, northwestern California: Physical interpretation of empirical relations, Geol. Soc. Am. Bull., 99, 579-594, doi:10.1130/0016-7606(1987)99<579:RGFASM >2.0.CO;2.

Jayko, A. S., M. C. Blake, R. J. McLaughlin, H. N. Ohlin, S. D. Ellen, and H. M. Kelsey (1989), Reconnaissance geologic map of the Covelo 30- by 60-Minute quadrangle, northern California, U.S. Geol. Surv. Misc. Field Invest. Map, $M F-2001$.

Keefer, D. K., and A. M. Johnson (1983), Earthflows: Morphology, mobilization and movement, U.S. Geol. Surv. Prof. Pap., 1256, 56 pp.

Kelsey, H. M. (1978), Earthflows in Franciscan mélange, Van Duzen river basin, Calif. Geol., 6, 361-364, doi:10.1130/0091-7613(1978)6<361: EIFMVD>2.0.CO;2.

Kilburn, C. R. J., and D. N. Petley (2003), Forecasting giant, catastrophic slope collapse: Lessons from Vajont, Northern Italy, Geomorphology, 54, 21-32, doi:10.1016/S0169-555X(03)00052-7.

Kirkby, M. J. (1971), Hillslope process-response models based on the continuity equation, Inst. Brit. Geogr, Spec. Publ., 3, 15-30.

Kirkby, M. J. (1987), General models of long-term slope evolution through mass movement, in Slope Stability: Geotechnical Engineering and Geomorphology, edited by M. G. Anderson and K. S. Richards, pp. 359-379, John Wiley, Chichester, U. K.

Kooi, H., and C. Beaumont (1996), Large-scale geomorphology; classical concepts reconciled and integrated with contemporary ideas via a surface processes model, J. Geophys. Res., 101(B2), 3361-3386, doi:10.1029/ 95JB01861. 
Korup, O. (2008), Rock type leaves topographic signature in landslidedominated mountain ranges, Geophys. Res. Lett., 35, L11402, doi:10.1029/2008GL034157.

Korup, O., J. J. Clague, R. L. Hermanns, K. Hewitt, A. L. Strom, and J. T. Weidinger (2007), Giant landslides, topography, and erosion, Earth Planet. Sci. Lett., 261, 578-589, doi:10.1016/j.eps1.2007.07.025.

Lock, J., H. Kelsey, K. Furlong, and A. Woolace (2006), Late Neogene and Quaternary landscape evolution of the northern California coast ranges: Evidence for Mendocino Triple Junction tectonics, Geol. Soc. Am. Bull., $118,1232-1246$, doi:10.1130/B25885.1.

Mackey, B. H., and J. J. Roering (2011), Sediment yield, spatial characteristics, and the long-term evolution of active earthflows determined from airborne LiDAR and historical aerial photographs, Eel River, California Geol. Soc. Am. Bull., doi:10.1130/B30306.1.1.

Mackey, B. H., J. J. Roering, and J. A. McKean (2009), Long-term kinematics and sediment flux of an active earthflow, Eel River, Calif. Geol., 37, 803-806, doi:10.1130/G30136A.1.

Malamud, B. D., D. L. Turcotte, F. Guzzetti, and P. Reichenbach (2004), Landslide inventories and their statistical properties, Earth Surf. Processes Landforms, 29, 687-711, doi:10.1002/esp.1064.

Malet, J. P., O. Maquaire, and E. Calais (2002), The use of global positioning system techniques for the continuous monitoring of landslides: Application to the Super-Sauze earthflow (Alpes-de-Haute-Provence, France), Geomorphology, 43, 33-54, doi:10.1016/S0169-555X(01)00098-8.

Maquaire, O., J. P. Malet, A. Remaitre, J. Locat, S. Klotz, and J. Guillon (2003), Instability conditions of marly hillslopes: Towards landsliding or gullying? The case of the Barcelonnette Basin, south east France, Eng. Geol., 70, 109-130, doi:10.1016/S0013-7952(03)00086-3.

Matsukura, Y., and K. Mizuno (1986), The influence of weathering on the geotechnical properties and slope angles of mudstone in the Mineoka earth-slide area, Japan, Earth Surf. Processes Landforms, 11, 263-273, doi:10.1002/esp.3290110304.

McKean, J. A., W. E. Dietrich, R. C. Finkel, J. R. Southon, and M. W. Caffee (1993), Quantification of soil production and downslope creep rates from cosmogenic ${ }^{10} \mathrm{Be}$ accumulations on a hillslope profile, Geology, 21, 343-346, doi:10.1130/0091-7613(1993)021<0343:QOSPAD>2.3.CO;2.

McLaughlin, R. J., S. D. Ellen, M. C. J. Blake, A. S. Jayko, W. P. Irwin, K. R. Aalto, G. A. Carver, and S. H. J. Clark (2000), Geology of the Cape Mendocino, Eureka, Garberville, and southwestern part of the Hayfork $30 \times 60$ minute quadrangles and adjacent offshore area, northern California, U.S. Geol. Surv. Misc. Field Stud. Map, MF-2336.

McSaveney, M. J., and G. A. Griffiths (1987), Drought, rain, and movement of a recurrent earthflow complex in New Zealand, Geology, 15 643-646, doi:10.1130/0091-7613(1987)15<643:DRAMOA>2.0.CO;2.

Merritts, D., and K. R. Vincent (1989), Geomorphic response of coastal streams to low, intermediate, and high rates of uplift, Mendocino triple junction region, northern California, Geol. Soc. Am. Bull., 101, 1373-1388, doi:10.1130/0016-7606(1989)101<1373:GROCST>2.3.CO;2.

Miller, D. J. (1995), Coupling GIS with physical models to assess deepseated landslide hazards, Environ. Eng. Geosci., 1, 263-276.

Montgomery, D. R., and M. T. Brandon (2002), Topographic controls on erosion rates in tectonically active mountain ranges, Earth Planet. Sci. Lett., 201, 481-489, doi:10.1016/S0012-821X(02)00725-2.

Montgomery, D. R., and W. E. Dietrich (1992), Channel initiation and the problem of landscape scale, Science, 255, 826-830, doi:10.1126/ science. 255.5046 .826 .

Oguchi, T. (1997), Drainage density and relative relief in humid steep mountains with frequent slope failure, Earth Surf. Processes Landforms, 22, 107-120, doi:10.1002/(SICI)1096-9837(199702)22:2<107::AIDESP680>3.0.CO;2-U.

Ollier, C. (1969), Weathering, Oliver and Boyd, Edinburgh, U. K.

Perron, J. T., J. W. Kirchner, W. E. Dietrich, and R. C. Finkel (2005), Testing model predictions of the evolution of valley spacing, Eos Trans. $A G U, 86(18)$, Fall Meet. Suppl., Abstract H33F-02.

Perron, J. T., W. E. Dietrich, and J. W. Kirchner (2008), Controls on the spacing of first-order valleys, J. Geophys. Res., 113, F04016, doi:10.1029/2007JF000977.

Perron, J. T., J. W. Kirchner, and W. E. Dietrich (2009), Formation of evenly spaced ridges and valleys, Nature, 460, 502-505, doi:10.1038/ nature 08174 .

Pyles, M. R., K. Mills, and G. Saunders (1987), Mechanics and stability of the Lookout Creek earth flow, Bull. Assoc. Eng. Geol., XXIV, 267-280.

Rempe, D. M., J. Oshun, W. E. Dietrich, R. Salve, and I. Fung (2010), Controls on the weathering front depth on hillslopes underlain by mudstones and sandstones, Abstract EP34A-05 presented at the 2010 Fall Meeting, AGU, San Francisco, Calif., 13-17 Dec.

Roering, J. J., J. W. Kirchner, and W. E. Dietrich (1999), Evidence for nonlinear, diffusive sediment transport on hillslopes and implications for landscape morphology, Water Resour. Res., 35, 853-870, doi:10.1029/ 1998WR900090.

Roering, J. J., J. W. Kirchner, and W. E. Dietrich (2005), Characterizing structural and lithologic controls on deep-seated landsliding: Implications for topographic relief and landscape evolution in the Oregon Coast Range, USA, Geol. Soc. Am. Bull., 117, 654-668, doi:10.1130/ B25567.1.

Roering, J. J., J. T. Perron, and J. W. Kirchner (2007), Functional relationships between denudation and hillslope form and relief, Earth Planet. Sci. Lett., 264, 245-258, doi:10.1016/j.epsl.2007.09.035.

Roering, J. J., L. L. Stimely, B. H. Mackey, and D. A. Schmidt (2009), Using DInSAR, airborne LiDAR, and archival air photos to quantify landsliding and sediment transport, Geophys. Res. Lett., 36, L19402, doi:10.1029/2009GL040374.

Schmidt, K. M., and D. R. Montgomery (1995), Limits to relief, Science, 270, 617-620, doi:10.1126/science.270.5236.617.

Schulz, W. H., J. W. Kean, and G. Wang (2009), Landslide movement in southwest Colorado triggered by atmospheric tides, Nat. Geosci., 2, 863-866, doi:10.1038/ngeo659.

Selby, M. J. (1993), Hillslope Materials and Processes, Oxford Univ. Press, Oxford, U. K.

Shampine, L. F., and M. W. Reichelt (1997), The MATLAB ODE suite, SIAM J. Sci. Comput., 18, 1-22, doi:10.1137/S1064827594276424.

Small, E. E., R. S. Anderson, and G. S. Hancock (1999), Estimates of the rate of regolith production using ${ }^{10} \mathrm{Be}$ and ${ }^{26} \mathrm{Al}$ from an alpine hillslope, Geomorphology, 27, 131-150, doi:10.1016/S0169-555X(98)00094-4.

Smith, T. R., and F. P. Bretherton (1972), Stability and the conservation of mass in drainage basin evolution, Water Resour. Res., 8, 1506-1529, doi:10.1029/WR008i006p01506.

Snyder, N. P., K. X. Whipple, G. E. Tucker, and D. J. Merritts (2000), Landscape response to tectonic forcing: Digital elevation model analysis of stream profiles in the Mendocino triple junction region, northern California, Geol. Soc. Am. Bull., 112, 1250-1263, doi:10.1130/00167606(2000)112<1250:LRTTFD $>2.0$. CO;2

Stark, C. P., and N. Hovius (2001), The characterization of landslide size distributions, Geophys. Res. Lett., 28(6), 1091-1094, doi:10.1029/ 2000GL008527.

Stephenson, W. J., and R. M. Kirk (2000), Development of shore platforms on Kaikoura Peninsula, South Island, New Zealand: II: The role of subaerial weathering, Geomorphology, 32, 43-56, doi:10.1016/S0169-555X (99)00062-8.

Swanson, F. J., and D. N. Swanston (1977), Complex mass-movement terrains in the western Cascade Range, Oregon, Rev. Eng. Geol., 3, $113-124$.

Swanston, D. N., R. R. Ziemer, and R. J. Janda (1995), Rate and mechanisms of progressive hillslope failure in the Redwood Creek basin, northwestern California, in Geomorphic Processes and Aquatic Habitat in the Redwood Creek Basin, Northwestern California, edited by K. M. Nolan, H. M Kelsey, and D. C. Marron, U.S. Geol. Surv. Prof. Pap. 1454 , pp. E1-E16, U.S. Gov. Print. Off., Washington, D. C.

Trotter, C. M. (1993), Weathering and regolith properties at an earthflow site, Q. J. Eng. Geol., 26, 163-178, doi:10.1144/GSL.QJEGH.1993. 026.003.02.

Tucker, G. E., and D. N. Bradley (2010), Trouble with diffusion: Reassessing hillslope erosion laws with a particle-based model, J. Geophys. Res. 115, F00A10, doi:10.1029/2009JF001264.

Tucker, G. E., and R. L. Bras (1998), Hillslope processes, drainage density, and landscape morphology, Water Resour. Res., 34, 2751-2764, doi:10.1029/98WR01474

Tucker, G. E., and R. L. Slingerland (1994), Erosional dynamics, flexural isostasy, and long-lived escarpments: A numerical modeling study, J. Geophys. Res., 99, 12,229-12,243, doi:10.1029/94JB00320.

Tucker, G. E., and R. L. Slingerland (1997), Drainage basin responses to climate change, Water Resour. Res., 33, 2031-2047, doi:10.1029/ 97WR00409.

Turcotte, D. L., and G. Schubert (2002), Geodynamics, 2nd ed., Cambridge Univ. Press, New York.

van der Beek, P., J. Braun, and K. Lambec (1999), Controls on postmid-Cretaceous landscape evolution in the southeastern highlands of Australia: Insights from numerical surface process models, J. Geophys. Res., 104(B3), 4945-4966, doi:10.1029/1998JB900060.

Vulliet, L. (2000), Natural slopes in slow movement, in Modeling in Geomechanics, edited by M. Zaman, J. R. Booker, and G. Gioda, pp. 654-676, John Wiley, Chichester, U. K.

Vulliet, L., and K. Hutter (1988a), Continuum model for natural slopes in slow movement, Geotechnique, 38, 199-217, doi:10.1680/geot.1988.38.2.199.

Vulliet, L., and K. Hutter (1988b), Set of constitutive models for soils under slow movement, J. Geotech. Eng., 114, 1022-1041. 
Vulliet, L., and K. Hutter (1988c), Viscous-type sliding laws for landslides, Can. Geotech. J., 25, 467-477, doi:10.1139/t88-052.

Wheatcroft, R. A., and C. K. Sommerfield (2005), River sediment flux and shelf sediment accumulation rates on the Pacific Northwest margin, Cont. Shelf Res., 25, 311-332, doi:10.1016/j.csr.2004.10.001.

Whipple, K. X. (2001), Fluvial landscape response time: How plausible is steady-state denudation?, Am. J. Sci., 301, 313-325, doi:10.2475/ ajs.301.4-5.313.

Whipple, K. X., and G. E. Tucker (1999), Dynamics of the stream-power incision model: Implications for height limits of mountain ranges, landscape response timescales, and research needs, J. Geophys. Res., 104(B8), 17,661-17,674, doi:10.1029/1999JB900120.

Whipple, K. X., and G. E. Tucker (2002), Implications of sediment-fluxdependent river incision models for landscape evolution, J. Geophys. Res., 107(B2), 2039, doi:10.1029/2000JB000044.

Willgoose, G., R. L. Bras, and I. Rodriguez-Iturbe (1991a), A coupled channel network growth and hillslope evolution model, 1. Theory, Water Resour. Res., 27, 1671-1684, doi:10.1029/91WR00935.
Willgoose, G., R. L. Bras, and I. Rodriguez-Iturbe (1991b), A coupled channel network growth and hillslope evolution model, 2. Nondimensionalization and application, Water Resour. Res., 27, 1685-1696, doi:10.1029/ 91WR00936.

Wills, C. J., and T. P. McCrink (2002), Comparing landslide inventories: The map depends on the method, Environ. Eng. Geosci., 8, 279-293, doi:10.2113/8.4.279.

Zhang, X., C. J. Phillips, and M. Marden (1991), Internal deformation of a fast-moving earthflow, Raukumara Peninsula, New Zealand, Geomorphology, 4, 145-154, doi:10.1016/0169-555X(91)90025-6.

A. M. Booth and J. J. Roering, Department of Geological Sciences, University of Oregon, Eugene, OR 97403-1272, USA. (abooth@ uoregon.edu) 